\title{
The Eccentricities of a Fading Southern Belle: Personalizing the Iconic Role of Amanda Wingfield in Tennessee Williams' "The Glass Menagerie"
}

Stephanie Freeman

Follow this and additional works at: https://researchrepository.wvu.edu/etd

\section{Recommended Citation}

Freeman, Stephanie, "The Eccentricities of a Fading Southern Belle: Personalizing the Iconic Role of Amanda Wingfield in Tennessee Williams' "The Glass Menagerie"'" (2015). Graduate Theses, Dissertations, and Problem Reports. 5624.

https://researchrepository.wvu.edu/etd/5624

This Thesis is protected by copyright and/or related rights. It has been brought to you by the The Research Repository @ WVU with permission from the rights-holder(s). You are free to use this Thesis in any way that is permitted by the copyright and related rights legislation that applies to your use. For other uses you must obtain permission from the rights-holder(s) directly, unless additional rights are indicated by a Creative Commons license in the record and/ or on the work itself. This Thesis has been accepted for inclusion in WVU Graduate Theses, Dissertations, and Problem Reports collection by an authorized administrator of The Research Repository @ WVU. For more information, please contact researchrepository@mail.wvu.edu. 


\section{The Eccentricities of a Fading Southern Belle: \\ Personalizing the Iconic Role of Amanda Wingfield \\ in Tennessee Williams' The Glass Menagerie}
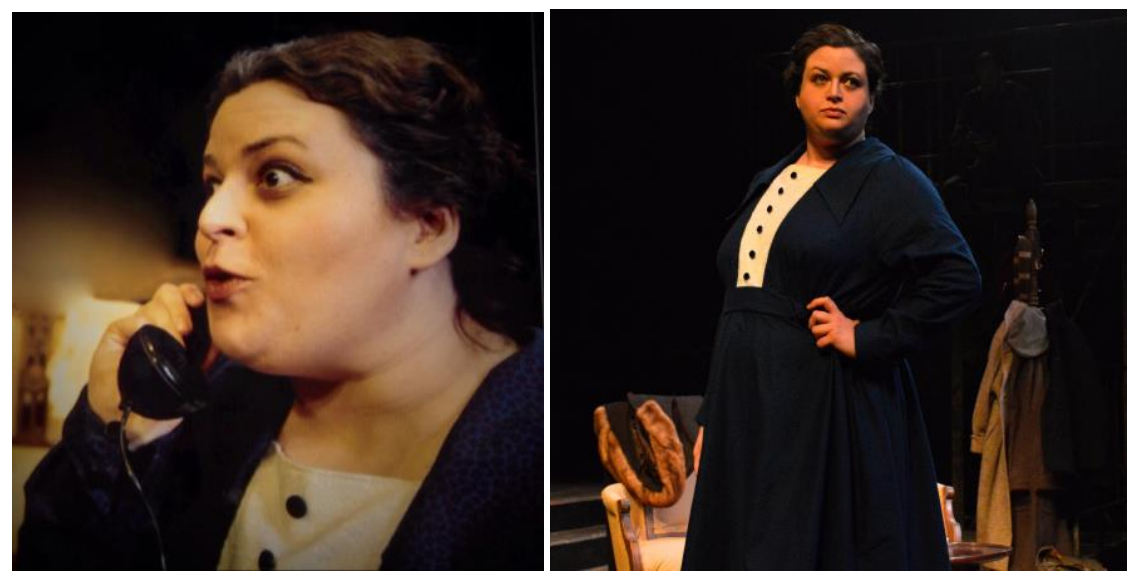

Stephanie Freeman

Thesis submitted to the

College of Creative Arts

at West Virginia University

in partial fulfillment of the requirements

for the degree of

Master of Fine Arts

in

Theatre, Acting Emphasis

Laura Hitt, M.A., Chair

Lee Blair, M.F.A.

Jessica Bishop, M.F.A.

School of Theatre \& Dance

Morgantown, West Virginia

2014

Keywords: Acting, Stella Adler, Tennessee Williams, The Glass Menagerie 


\begin{abstract}
The Eccentricities of a Fading Southern Belle: Personalizing the Iconic Role of Amanda Wingfield in Tennessee Williams' The Glass Menagerie
\end{abstract}

Stephanie Freeman

This document chronicles, from the first read-through to the final curtain call, the process of diving into the role of Amanda Wingfield from Tennessee Williams' The Glass Menagerie. It details my path toward character development (personalizing Amanda's point of view and drawing on others for inspiration), the rehearsal process, and ultimately how I couldn't help but be changed by the experience. The opportunity to play one of Tennessee Williams' most famous women brought with it a myriad of emotions at the start - from excitement (due to the fact that this was a dream come true for a thesis role) — to absolute incredulity that I would be able to master this character's endless diatribes and ramblings without turning her into a cartoon. Having been portrayed by legendary actors of both stage and screen for seventy years, I wanted to make sure my work on the character lived up to its iconic status, but also, I wanted to explore a new side to this very complicated mother. 


\section{Acknowledgements}

I would like to thank the wonderful people who have inspired my growth as an actor during my time at West Virginia University:

Laura Hitt for agreeing to chair my committee, helping me to breathe through the performance process, and for her encouragement and positivity;

Lee Blair for his kind words, wisdom, and sense of humor-it makes my day if I can make him laugh;

Jessica Bishop for her encouragement - even when I'm dreadfully out of shapeshe lets me flail about in reckless abandon, and always holds out the hope that one day I can explore stillness. (There's always hope);

Kathleen Amshoff for giving me this amazing opportunity to play such an iconic role for my thesis;

my late grandmother, Jean, who helped me see Amanda's point of view;

and, most importantly, my parents, who when told that I would be pursuing a career in theatre responded with nothing but support, excitement, and questions concerning ticket pricing. They both truly meant it when they said that they would support anything that made me happy, and that means the world to me. 


\section{Table of Contents}

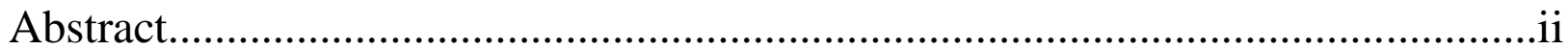

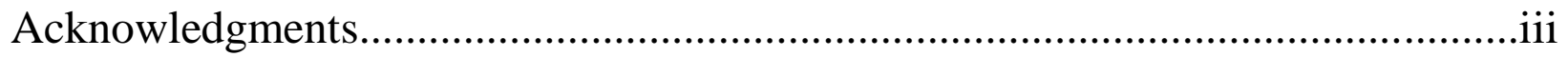

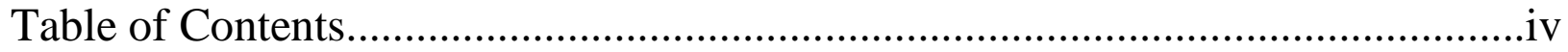

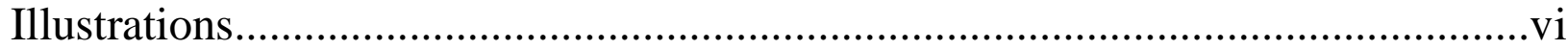

Introduction

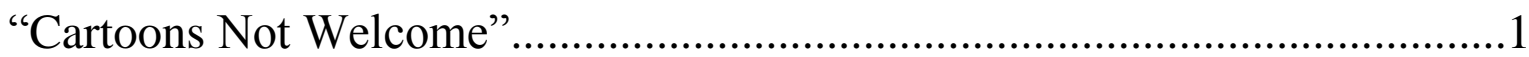

Research

"Tennessee to a Tee"

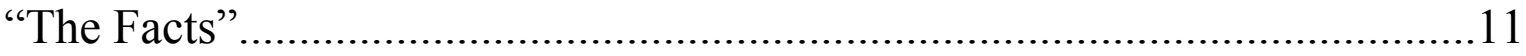

"The Distance Between Two Places"........................................................15

“The Mother Lode: Edwina's Difficult Relationships".................................19

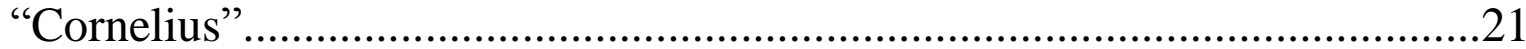

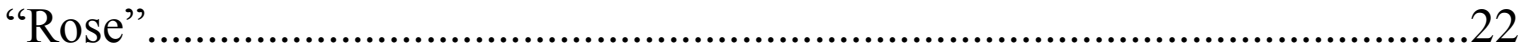

Character Development

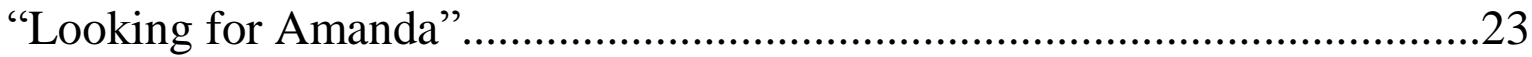

"Two-Sided Grandmother: Personal Experience"...........................................25

"Shaping Sound and Facing Other Performances"......................................27

Plot Summary

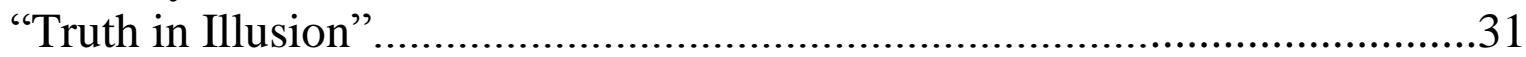

Rehearsal Process

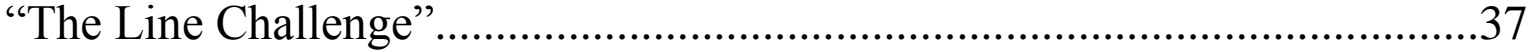

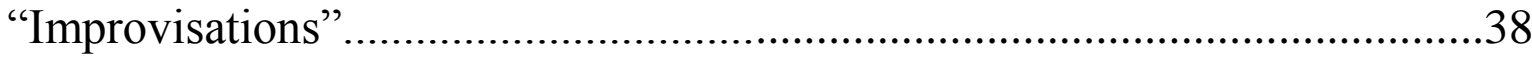

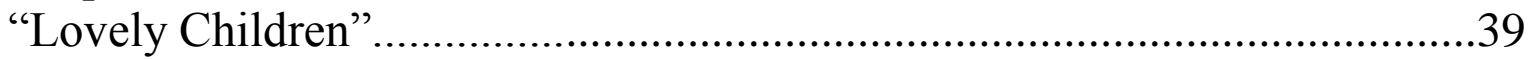

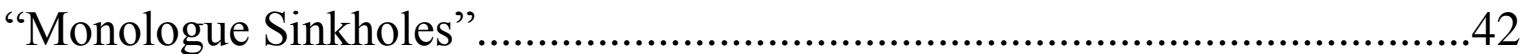

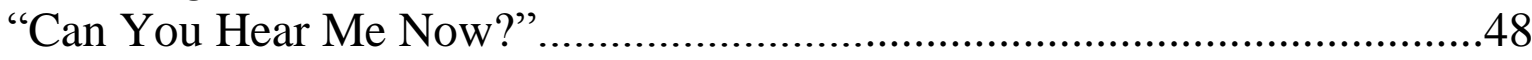

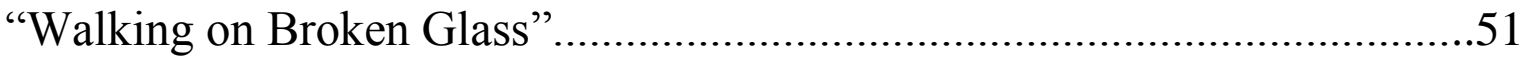

Performance

"Center and Go" 


\section{Personal Conclusion}

"So, Sue Me-I'm Sensitive".

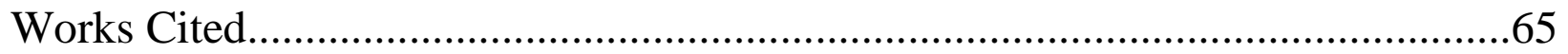




\section{Illustrations}

Fig. 1. Laurette Taylor in the Original Broadway Production. "Gilbert Theater Examiner:

Arizona Theatre Company to Present 'The Glass Menagerie.'" Examiner.com. N.p., n.d.

Web. 29 July 2014.

Fig. 2. Cherry Jones as Amanda Wingfield on Broadway, Booth Theatre, 2013. "Cherry Jones Is

a Formidable Amanda in Tennessee Williams' "'The Glass Menagerie.'” The Komisar Scoop. N.p., n.d. Web. 29 July 2014.

Fig. 3. Tennessee Williams, 1940. "Rare Tennessee Williams Story Published." Yahoo Celebrity. N.p., n.d. Web. 29 July 2014.

Fig. 4. Famous-Barr, Co., St. Louis, Missouri (Lower floors of Railway Exchange Building, 1913) The Department Store Museum. N.p., n.d. Web. 27 Sept. 2014.

Fig. 5. Edwina Williams, Regent of the DAR in St. Louis, in 1936. Williams, Edwina Dakin and Lucy Freeman. Remember Me to Tom. St. Louis: Sunrise, 1980. Print.

Fig. 6. Edwina Dakin Williams with Rose and Thomas. "Columbus: Tennessee Williams \& Eudora Welty." Southern Literary Trail. 2014.Web. 29 July 2014.

Fig. 7. Edwina Williams as a debutante. Williams, Edwina Dakin and Lucy Freeman. Remember Me to Tom. St. Louis: Sunrise, 1980. Print.

Fig. 8. Joanne Woodward as Amanda Wingfield, 1987 (film). "100 Worst Oscar Snubs Ever: Nos. 100-76." Entertainment Weekly. 20 Jan. 2009. Web. 6 June 2014.

Fig. 9. Geraldine Page. Deja, Andreas. "Geraldine Page Is Madame Medusa." Deja View. N.p., 13 Sept. 2013. Web. 29 July 2014.

Fig. 10. Off-book Rehearsal, Scene One. Photo by Shannon Dickerson. 


\section{Cartoons Not Welcome}

\section{Introduction}

Laurette Taylor, Joanne Woodward, Jessica Tandy, Katharine Hepburn, Jessica Lange, and most recently, Cherry Jones, have all stepped into the fussy shoes of Amanda Wingfield over the years. No pressure, right? The first thing that came to mind when I was cast in this role is that I really hoped that I wouldn't turn Amanda into a cartoon character. The poetic language of Williams and the languid, sweltering atmosphere of his work has made an indelible impression on American popular culture for seventy years, and of course when a style is so distinct, it inspires a stereotypical slant, no matter how unintentional. The character is twenty years older than I am, physically my polar opposite by being described generally as slight and frail, and dominates the play by mooning about and rambling, except for the famous Jim and Laura interlude. Even though there was some trepidation at first, I was very grateful for the challenge. Being a character actor, meaty roles are rare. Whether it was the fact that I am from the South and Tennessee Williams is our cultural uncle, or that I crave opportunities to play eccentric, wounded characters that might provoke a bit of laughter and a few tears, I felt really comfortable at the beginning of the process. In addition, it helped that I could finally put my Southern dialect habits to good use!

Upon beginning the research over the winter break, I knew that The Glass Menagerie (TGM) was Tennessee Williams' most autobiographical play. Before the audition process, I was familiar with the story since it was a requirement for an introductory theatre class that I took at the University of Alabama. During my first year at WVU, I sat in on a Text Analysis demo class for a Visiting Artist candidate whose required lecture was on, of course, TGM. Ever a game participant, when asked what I thought of the play, I replied, "Well, I read it about ten years ago, but I do remember that the mother was a pain in the ass." Oh, life is funny. 


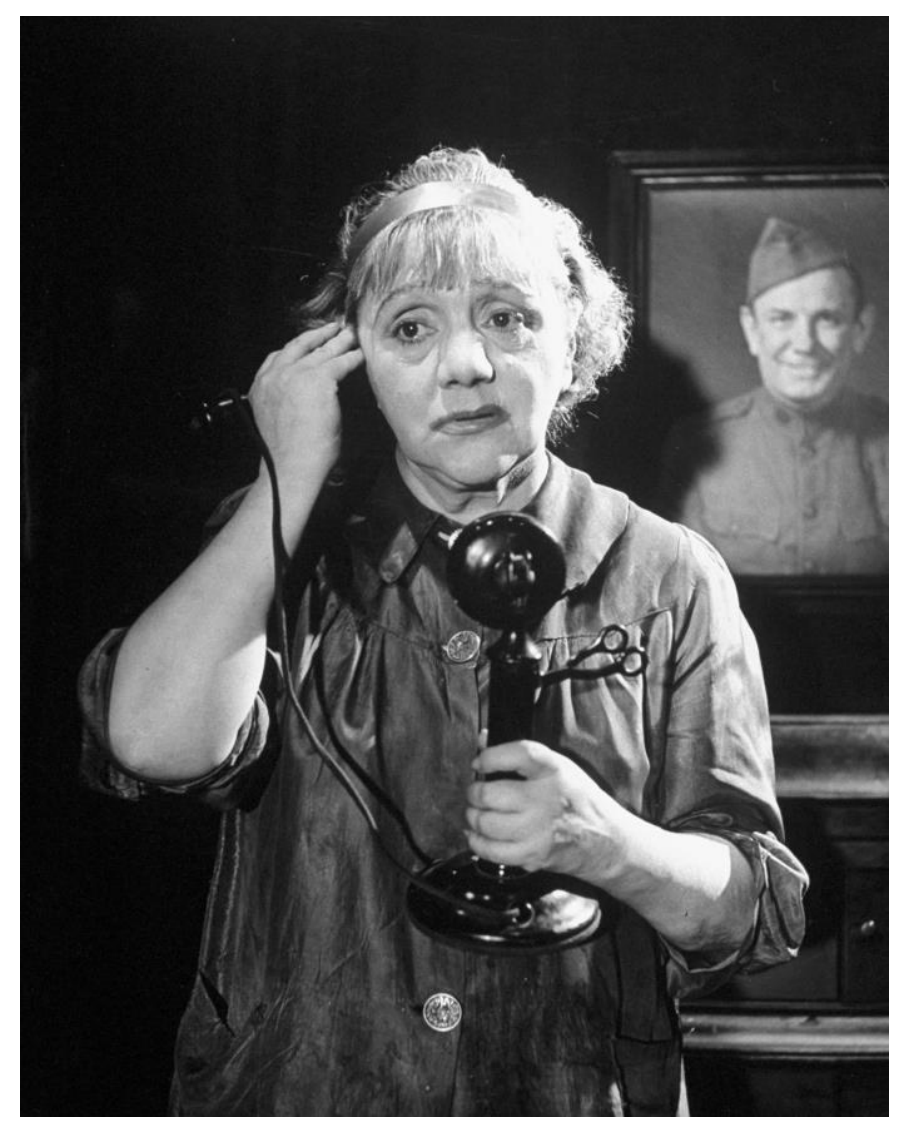

Fig. 1. Laurette Taylor in the original Broadway production

I didn't want to dismiss my feelings about the play as an audience member, but I knew that I, of course, had to be on Amanda's side. I was "Team Amanda" and all of her decisions in the play needed to be mine as well. The original actor who portrayed Amanda, Laurette Taylor, received an enormous amount of praise for her ethereal performance. Due to her struggle with alcoholism, she also found the role to be a bit redemptive of her career. Robert Gottlieb, (former editor of The New Yorker) who saw the production at the age of fifteen, described her performance, saying:

She simply didn't act. Or so it appeared. She wasn't an actress; she was a tired, silly, irritating, touching, fraught, aging woman with no self-awareness, no censor for her ceaseless flow of words, no sense of the effect she was having on her children — or the audience. It was as if you were listening in on the stream of her consciousness. Her self-pitying yet valiant voice, reflecting both the desperation of her situation and the faded remnants of her Southern-belle charm, was 
maddening, yet somehow endearing. You wanted to hug her, to swat her, to run from her-in other words, you reacted to her just the way her son, Tom, did (Gottlieb).

Taylor was an uncanny replica of Edwina Williams, Williams' mother, and with the playwright observing many rehearsals, her mannerisms and phrasing were made to hit just the right note. If they didn't, Williams intervened (E. Williams, 146). Upon seeing Taylor's performance at the premiere, December 26, 1944, Edwina, verklempt and flustered, denied that she herself was Amanda, claiming the only similarity was that they both liked jonquils (E. Williams, 149). In her memoir, Remember Me to Tom, Edwina discusses her jarring conversation with Laurette Taylor after the show:

I entered Laurette's dressing room, not knowing what to expect, for she was sometimes quite eccentric. She was sitting with her feet propped up on the radiator, trying to keep warm. Before I had a chance to get out a word, she greeted me. 'Well, how did you like you'seff, Miz' Williams?' she asked. I was so shocked I didn't know what to say. It had not occurred to me as I watched Tom's play that $I$ was Amanda. But I recovered quickly. (E. Williams, 148)

This kind of denial was right up Edwina and Amanda's alley, and who could blame her? To be presented on the stage as an eccentric, tragic, annoying, pitiable, and pathetic figure, and then to be publicly accused of being the barrier between her children and their dreams is a lot to take in. However, Edwina was able to view Amanda as a creation of her son's imagination. That distance probably saved her a bit of grief, even if only a very small amount. The very poetic outcome that arose - the success of the play — enabled Williams to gift Edwina with half of the royalties in order that she would finally be able to leave his alcoholic father, Cornelius (Collins). Though the circumstances of the Wingfield and Williams households were slightly different, that relationship 
between mother and son is the truth from Williams' point of view. It is his point of view that guides the play. The key component that cannot be overlooked is that a mother and a son, who loved each other very much, were tearing each other apart over different expectations. Williams wouldn't desert his mother in the manner that Tom does. But the essential need for Williams to escape his mother's tight grasp, to not follow in his father's footsteps at the shoe factory, and to spare himself the agony of seeing his sister Rose combat mental illness, meant that he had to leave. He was an artist who had to live on his own terms in order to reach his full potential. It became a goal of mine throughout the entire process to discover what it was like to be the mother of that kind of person. In fact, I had to discover what it was like to be a mother, period.

The play is told through Tom's (or really Williams') eyes. I believe that this dynamic has the strongest effect on the way that the role of Amanda is approached. It is Tom's memory of his mother that informs the character (which involves all of the error that memory breeds). The characterization of Amanda herself—as seen through Tom—could be a bit embellished, and that's where the fun began in trying to construct this character. The big question I asked myself was, "How much do I have to adhere to the historical figure of Edwina?" The second question was, "How much could I let Amanda Wingfield stand alone as just a character in her own right?" Most actors cast as Amanda are willowy and feminine, a physical representation of who Amanda was as a young girl, but just a little wilted from age. My Amanda let herself go, in her later years. I'm physically nowhere near how Williams described her as "a little woman of great but confused vitality" (E. Williams, 148). My own physicality made me look in a new direction as to how she could be portrayed.

My body type has influenced every character that I've played; there has never been a way around it. Pleasantly plump. Plus-sized. I'm big-I'm a big woman. Though it hasn't always 
been an easy road towards acceptance, I think now that I'm pushing thirty I'm learning just to go with the flow. Being bigger has afforded me the opportunity to play older roles in educational theatre, and even in some very wacky professional productions. All of my years watching screwball comedies have made me aware of the assets of being more rotund. When I'm in "character mode" on stage, I know just how my body is being viewed, and that my overdone gestures or quick changes of pace just seem to get laughs. I tend to be extremely physical on stage. Trying to uphold some silly standard that women are supposed to look perfectly poised and statuesque at all times on stage or film is ludicrous. The entertainment industry desperately tries to put women in a very tiny box. But those performers who broke barriers for other women in comedy — Carol Burnett, Dawn French, Jennifer Saunders, Gilda Radnor, Elaine Stritch, Tina Fey, Andrea Martin — were the ones who have inspired me the most (not some glamorous ingénues whose only task in a play or film is to fall in love and be fallen in love with—such a bore).

Over the course of the last ten years or so, I've really been influenced by Dawn French and Miranda Hart, two British comediennes who have built careers on the fact that they have their very own unique looks: Dawn French is very short, round and charming, while Miranda Hart is larger, around 6' 1 ," and also very charming. Their delightful confidence mixed with down-to-earth self-deprecation entertains, warms the heart, and provides laugh-out-loud hilarity. They are absolutely beautiful women (who may not fit into some silly notion of movie star beauty) most especially because their belief in themselves affects their audiences. This kind of confidence by proxy that I gain from watching them has had a major influence on the work I've done at WVU. Their work inspired my process. Even though TGM is not a laugh riot, to say the least, Amanda charms and performs for the other characters throughout the show, until she 
cannot hold it together any longer. She has some great lines that she may or may not realize are comical. I think the moments of levity in the play are desperately needed, and I knew that I would have a lot of fun with her eccentricities. Comedy means freedom to me. I didn't want to get laughs just for the sake of it, but this is a drama peppered with a few lighter moments. If Amanda's exasperating tendencies to meddle could be viewed as humorous instead of just consistently aggravating from the audience's perspective, perhaps it could make the ending that much more heartbreaking. This play can be a very strong cup of coffee for some people. I just wanted to add a little sugar. Well, if I'm honest_-aspartame. Amanda is still a piece of work.

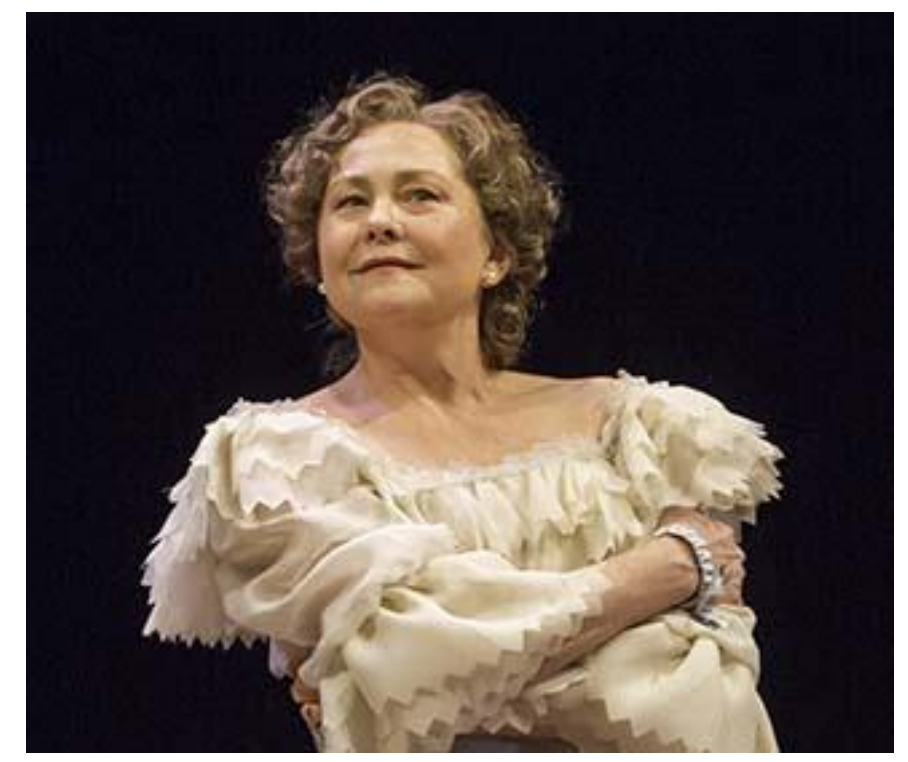

Fig. 2. Cherry Jones as Amanda Wingfield on Broadway, Booth Theatre, 2013

Looking at the stills from the 2013 revival of TGM on Broadway, with the brilliant Cherry Jones at the helm, I was led to look at trailers, clips, anything that I could get my hands on. Actually seeing the production was out of the question, due to time and the lack of funds. Cherry Jones is not frail. Cherry Jones commands the stage like a general. Why can't Amanda be a physical representation of who she is - a survivor? Why couldn't her physicality mimic her strong-willed spirit? (And it would have to, since I am heavy and can only play the cards I'm 
dealt). This single mother scraped together a life for herself and her children. Now she combats poverty and disillusionment during the Great Depression, all with the ability to sparkle with a liveliness of days past. Amanda charges ahead and completes every difficult task before her with her head held high. In my mind, I could see her being such a cheerleader for her children that she had a marching band playing behind her most of the time!

The foundation for my portrayal of Amanda would be Edwina Williams, the original prototype. But my Amanda would grow and differ from the usual trappings. Or at least I hoped that she would, without being a clown-since it's in my nature to be a clown. It's a very thin line between acknowledging Amanda's eccentricities rather than drowning in them. At the start I hoped that I could manage a kind of balance. Throughout the rehearsal process, I allowed myself to rely on a lot of humor. TGM can be a dirge-like museum piece. The audience must care for the characters before they fall off the face of the earth in despair. Whether my portrayal was going to be a success or failure should have been at the forefront of my mind, but I think at the onset of the process I was just so excited to come back from winter break and begin working on what would be the largest role I would ever get to play at WVU. I tried my best to "rise and shine!" 


\section{Research}

\section{Tennessee to a Tee}

Murder, cannibalism, castration, madness, incest, rape, adultery, nymphomania, homosexuality. There exists no savage act about which my son has not written. Yet, his plays are filled with beauty. And they offer truth, truth that many of us do not like to face (E. Williams, 13).

—Edwina Dakin Williams, Remember Me to Tom

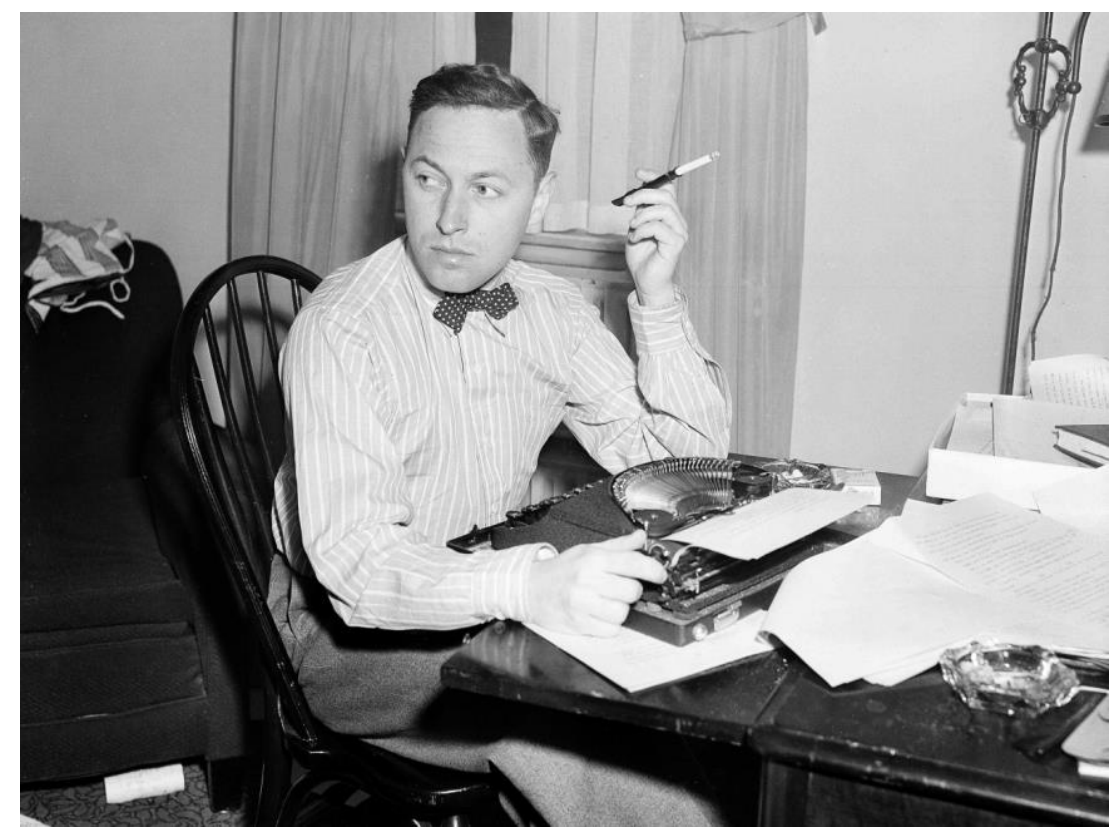

Fig. 3. Tennessee Williams, 1940

Suffice it to say, Tom is Tennessee (born Thomas Lanier Williams), Amanda is his mother, Edwina, and Laura is his mentally ill sister, Rose. This is a very general statement for a work that plays host to a rather universal problem - familial obligation versus individual and artistic preservation. However, one of the reasons this play is admired by so many is that it closely mirrors its author-and it's just a fantastic story even without Williams' personal association. When art helps to define truthful moments in a person's life, it strikes a deep chord. The playwright essentially puts himself on the stage and lets the audience in on a poetically enhanced version of the situations that shaped his worldview. In knowing that a play reflects the 
life of the playwright, the first instinct demands a read of a biography and memoirs. We want to assign grounded attributes to characters as representations of real people. This can be very helpful and a way to honor the playwright's intention. However, after a while, it may hamper creativity if the cold facts aren't enhanced with the insight of imagination. The research results in a fictional character based on Edwina Williams, not Edwina herself.

The similarities of Williams' own life with that of the Wingfields are familiar talking points. On the other hand, I was (and still am) interested in the differences. Williams' true circumstances were shifted symbolically to fit the dynamic of the play while still relating to his personal experiences. A combination of forces came out in Amanda such as Williams' father's unwillingness to understand him in conjunction with his mother's anxiety over their living situation. To try and understand the playwright's creative voice allowed me to tap into my own process as an actor, interpreting a character and a story. TGM became one of the most pure personal catharses that Williams created. I venture to say that it was a type of therapy that only his particular work in the theatre, in the company of other artists, could provide. Though TGM is very informative of Williams' attitude toward the circumstances of his youth — “truth in the pleasant disguise of illusion"-Williams through his many travels, as well as his ordeals with his very dramatic family, became the fodder for his own success. His creative voice through the lens of his dysfunctional family life became his salvation and truly informs the TGM journey.

The hope that springs from every revival of a classic is that new points of view may be found, perhaps with different answers to old questions. Williams' poetic style led me to feel that there was room to grow in the character of Amanda without having to constantly be boxed in by her origins. However, I first locked down as many of the facts as I could. It may be pretentious to compare one with the other, but in the way a jazz musician is trained classically before they 
develop their own style, hopefully that's the way an actor may approach a Williams charactertradition, followed by poetic imagination or creative license. And if it's not an acceptable reason for steering away from convention then here's a more truthful reason: I really needed some wiggle room, especially seeing as how Amanda was so over-the-top. I had to justify for myself what she was doing and in a manner where hopefully I wasn't channeling Carol Burnett's impression of Joan Crawford. So, I began the process by looking at the Williams and Wingfield families side by side to better discern the motivation Williams had for TGM's dramatic structure. 


\section{The Facts}

Williams' early history mimics a lot of the setup of $T G M$, and a lot of those struggles of trying to find himself and the direction that he wanted to travel in life are also Tom's obstacles. When he was seven, Williams' family stepped down a bit in the world and moved from the respectable societal position of being part of a minister's family in the small town of Clarksdale, Mississippi (Edwina's father was an Episcopal pastor) to St. Louis. Williams' father, Cornelius, was hired as a manager at the International Shoe Company, which would later become Williams' quarter-life crisis in his twenties for a short period and subsequently the inspiration for Tom's unhappiness (E. Williams, 23; Thornton, x).

Williams was influenced by Anton Chekhov and D. H. Lawrence, among others. His need to soak up as much inspiration as possible from these very liberal thinkers of their time comes into play during the fight in Scene Three (Thornton, xi). Tom confronts Amanda about her rifling through his things and taking away "that hideous book by that insane Mr. Lawrence." It wasn't difficult to understand where Amanda was coming from: she was terrified of the unknown. Lawrence's works caused huge outcries upon publication because of the Edwardian public's aversion to depictions of sexuality, especially homosexuality. Even if the particular Lawrence book Tom had wasn't graphic (I imagined Sons and Lovers, which details a very close relationship between a mother and a son—very telling), just seeing Lawrence's name on the book would make her fly off the handle due to his association with obscenity, and in a conservative household in 1930s St. Louis, that kind of subject matter would be unthinkable. While it would be easy to view Amanda through a 2014 lens and demonize her for not accepting her son's homosexuality and essentially nailing his closet door shut as it were, Amanda responds from a place of Depression-era fear where books were burned and fear-invoking leaders 
possessed immense cultural sway. She honestly has no idea what Tom does at night, and the imagined contents of his books just heightens the scenarios running through her mind. If he is engaging in certain activities which go against her religious beliefs, he could be lost to her forever, and all that is in her power is to shame him. Since he's a grown man, she has no real control over him except guilt. This facet of the relationship between Tom and Amanda is a mirror image of Williams' and one of his mother's epic battles.

Purposely absent (yet in the form of the looming presence of the Wingfields' absentee father by way of a photograph) is Cornelius Williams, Tennessee's alcoholic salesman turned shoe factory manager father. Cornelius may have been emotionally unavailable, and quite violent at times, but he never truly abandoned his family. With one parent in the spotlight of Williams' story, an interpretation of Amanda's behavior could be that some of Cornelius' personality traits and attitudes could have been added to her character. In actual fact, Cornelius, not Edwina, steered Williams toward becoming a clerk at the International Shoe Company in St. Louis. Cornelius pulled Williams out of the University of Missouri in 1932 due to his poor performance. Williams was more focused on writing his short stories and poetry than his studies (Thornton, $x, x i)$. Tom goes to work out of his own understanding of his obligations, along with a major dose of guilt and strong-arming from Amanda, whereas Cornelius had a lot to do with Williams' suffocation at the shoe factory. Amanda was all for Tom taking night classes, much like Edwina Williams was actually very supportive of her son's writing, while Cornelius saw his son's education as immaterial. There is a nice shading of Cornelius in Amanda to give her a bit of an edge as the driving force behind his limbo-like state at the factory, but of course Edwina takes up about ninety-percent of the character's attributes. Amanda is a bit flintier than Edwina at times and represents Cornelius' views. So, just how nasty could she get, or how conniving did 
Williams want to make her, since his personal situation was influenced by his father, as well? Or moreover, how much could Amanda be pushed into the category of villain, though her relationship with her children is more complex than one label would allow?

Much like Tom, Williams spent sleepless, coffee and cigarette-filled nights churning out stories, but ended up returning to school multiple times after leaving the factory in 1935 due to exhaustion. (He enrolled at Washington University, in particular, which he alludes to in the play (Thornton, x,xi). Amanda wants Tom to take night classes, which he shrugs off, but Williams wanted to return to school, though not particularly in pursuit of a degree (Thornton, x, xi). Tom's unwillingness to adhere to any sort of structure makes it seem like Williams infused a lot more courage into this character than he had for himself. It could be interpreted that Williams was still playing it safe_ — as in he didn't completely cut ties with his family.

His early struggles had a profound effect on his new identity as an artist. In 1938, in order to enter a play contest sponsored by the Group Theatre for playwrights under the age of twentyfive, Williams, aged twenty-eight, lied about his age and submitted his work under 'Tennessee' Williams (taking his father's birthplace as his first name). He had previously been published using his full given name (Thornton, xii). In the spring of 1943, Williams landed a job as a screenwriter at MGM, but he was more driven to work on his own personal material. He turned to his sister Rose for inspiration who had just undergone a prefrontal lobotomy in January of that year after being diagnosed with schizophrenia (Thornton, xiii). During this time Williams began working on his play The Gentleman Caller, which would later evolve into TGM, pulled primarily from his short story "Portrait of a Girl in Glass" (Thornton, xiii).

Through the character of Tom, Williams pours out his heart and gives us (and himself) the creative and therapeutic gift of framing his own personal problems on a grand theatrical 
scale. The plot differs from his own life in order to create a drama structured with the most explosive sort of conflict between mother and son. My further understanding of the play was aided by my search for these differences. Because of this contrast between history and fiction, I felt confident that I wouldn't need to be bound by research alone in order to discover Amanda's point of view. 


\section{The Distance Between Two Places}

For some reason, thinking about the 1930s makes me think of Christmas. I suppose it's because most of the holiday films that I watch every year are made in that era, where everything seemed to be so quaint, polite, and lovely. I love plays set in the 1930s. This is my second 1930s production at WVU, the first being Lend Me a Tenor (which still tops my list as the most fun on and off stage experience I've ever had doing a play). There is a genuineness to this era (what is portrayed in films, anyway) that makes our modern popular culture look absolutely vapid, and most of the time, barbaric. People carried themselves with a bit more dignity. Values were more important. There is a collective nostalgia in current popular culture for this era, not for the poverty and political strife, but for a time when families had no choice but to band together. Throughout the rehearsal process, we were told to think about the kind of financial situation the Wingfields were in, and how that might ground us to the space. I just made an effort to be careful with things; I suppose that was the most important thing to do. What you own, you must protect. I looked at photographs, watched films from this era, and marinated in this specific period where morals had to be appreciated more than possessions. The qualities of being hardworking and dependable were the main currency.

As far as St. Louis in the 1930s, I was mostly concerned with what would be a part of Amanda's life and what would be part of her day-to-day routine. Being forced to work at Famous-Barr, a department store, is a step down from being a debutante, but holding a position there, even if it means modeling brassieres, allows for a sense of dignity. 


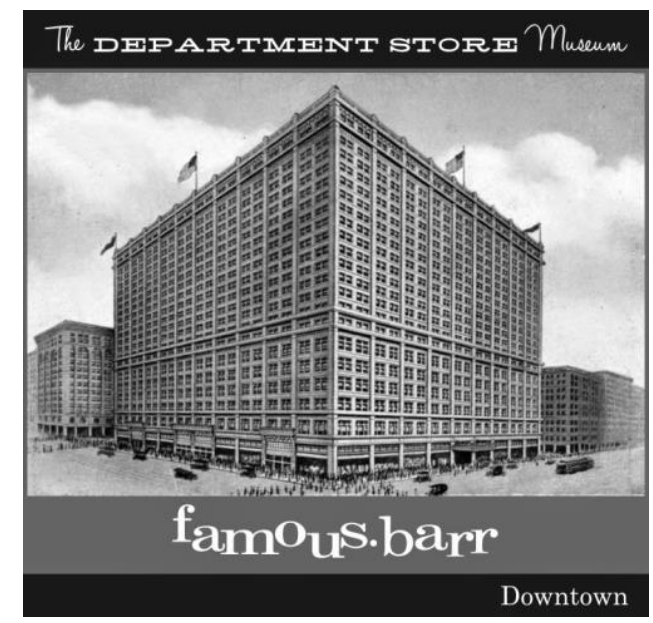

Fig. 4. Famous-Barr, Co., St. Louis, Missouri (Lower floors of Railway Exchange Building, 1913)

Amanda works part-time, while her children are obliged to go out into the world to do a lot of the heavy lifting. This is due to her age and the fact that she feels it is more important to be at home providing stability for her family. Also, now that her children are grown it is just expected that they would contribute to the well-being of the family unit.

Bringing another place and time with her into every situation is Amanda's most valuable asset. It is very important that her role at the local chapter of the Daughters of the American Revolution (DAR) is included in the play. Lineage is very important to Amanda (and in turn, Edwina). In my opinion, Amanda has a difficult time keeping pace with the other ladies because of her financial situation. She cannot truly be the social butterfly she was in her younger days in Mississippi, so "Amanda's connection to society is maintained primarily in her imagination when she talks about her suitors in Blue Mountain" as well as her efforts at the DAR (Janardanan, 42). She is not the most popular woman at the meetings based on the difficulties she has in getting women to buy subscriptions (even though she was about to be inducted as an officer before finding out about the Rubicam mishap). Amanda has no real friends. Her children do not respect her. On the surface cheerful, yet incredibly lonely, Amanda is the most wounded character I have ever portrayed. Her relationship to her environment is just as complicated as her internal struggle! 


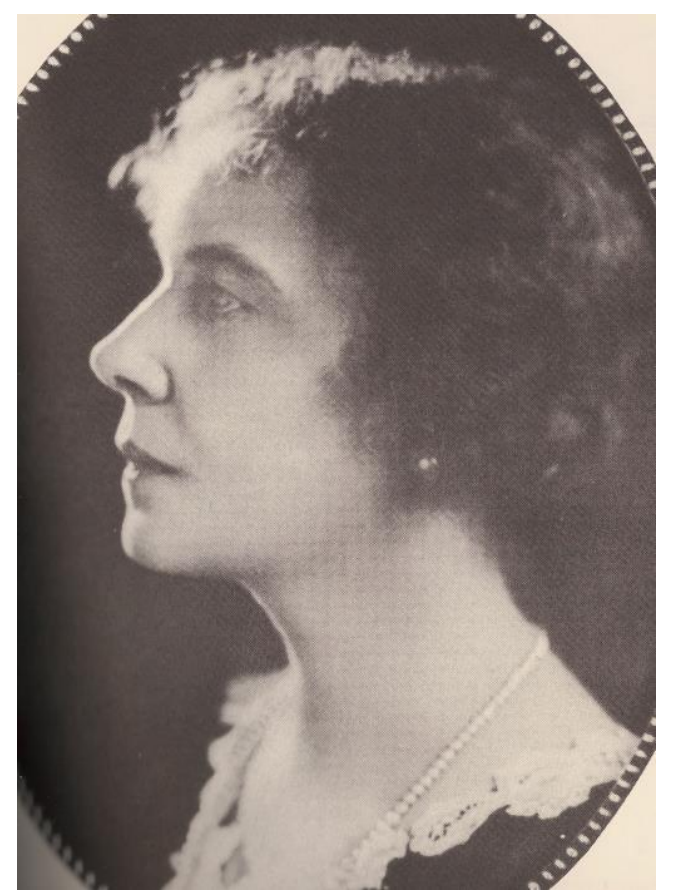

Fig. 5. Edwina Williams, Regent of the DAR in St. Louis, in 1936

Along with her can-do attitude, she has truly good manners and a valuable upbringing. In her mind, if she can retain the type of social etiquette standards she had in the South, then she and her two children could avoid being like the rabble living from hand to mouth. Good breeding can mask present financial constraints. When all hope is lost, feeling morally superior to others sustains Amanda. Her sense of self, flawed however it may be, is what keeps her moving in this very bleak environment that the Great Depression created.

Outside of the apartment is not a very cheerful place. Bums and hussies frequent a dance hall across the alley. The tenement building is far too crowded with families who in Amanda's mind have no breeding whatsoever. The long walks in the dirty snow on winter mornings and afternoons are unbearable. I tried to bring the imagery of dirty snow with me as I prepared for the Rubicam's scene. I imagined a couple engaged in lewd behavior as I was preparing for Jim's entrance. Little bits and pieces of imagery helped me the most—imagining how difficult it was to keep a positive attitude when everyone else was basically giving up-falling into depravity and 
desperate actions. Composure and glossing over the truth had to be Amanda's bread and butter.

Due to this, her actions could become very grating to her children. She demanded that they fall in line! 
The Mother Lode: Edwina's Difficult Relationships

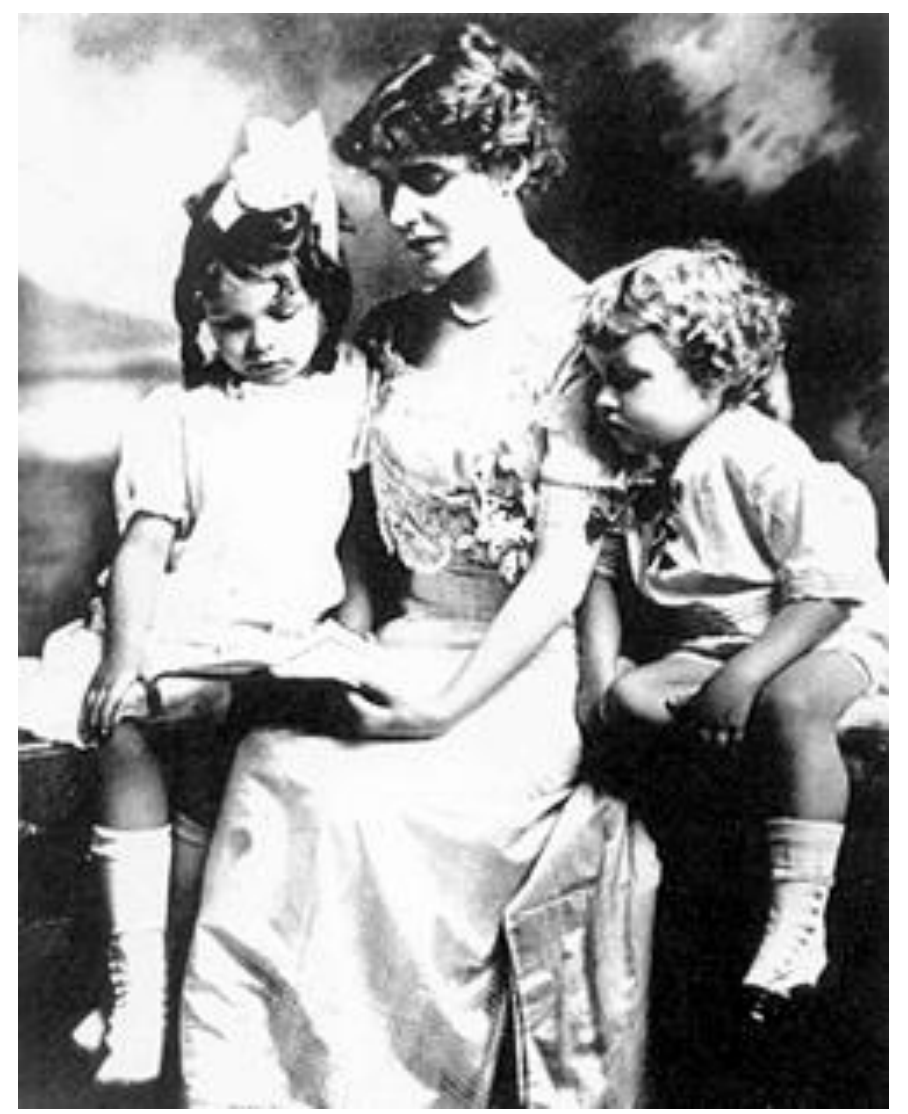

Fig. 6. Edwina Dakin Williams with Rose and Thomas

To say Edwina Williams was a complicated woman is an understatement. Full of charm, life, and love for her children, she, like Amanda, faced circumstances in her adulthood that she was not prepared for, and coped in the best way possible. To deal with a violent alcoholic husband while also raising three children created behavior that may have come off as a bit highstrung to the average passerby. But in reading her memoir, Remember Me to Tom, I truly felt that in her own way she was trying to do the best for her children, but was just utterly trapped in a terrible marriage. 


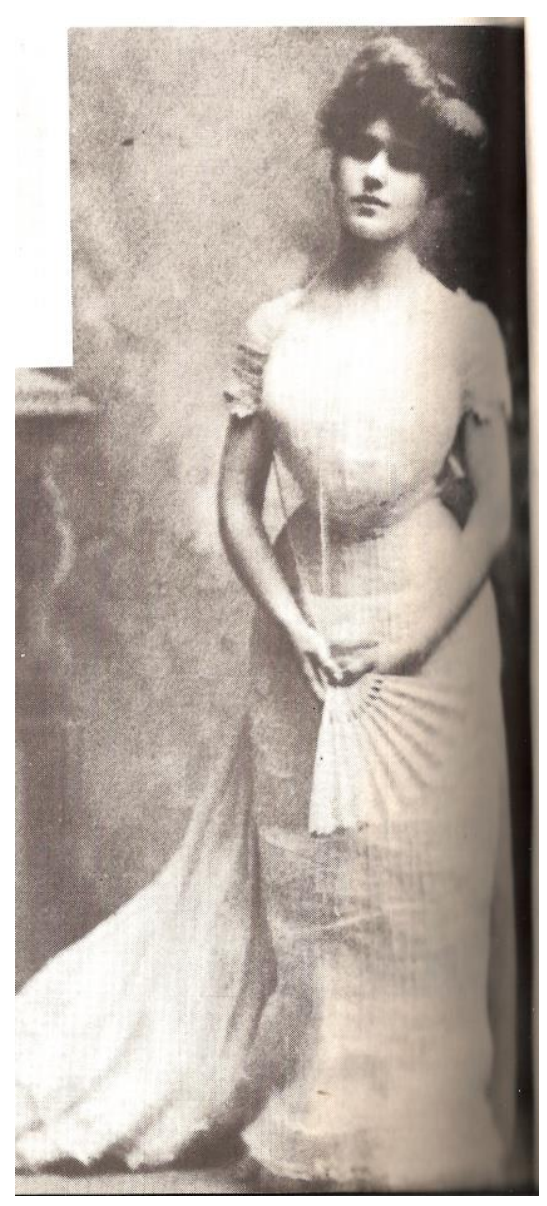

Fig. 7. Edwina Williams as a debutante.

In my personal experience of the South and religion, I believe that there is sincere, true belief in most, but because church going is so intertwined with social status there is a lack of individualization and discernment that is ever-present. Edwina, as the daughter of a minister, enjoyed a lovely social life because the church is the social hub of any small town in the South. She filled the role of hostess and role model quite well. However, choosing the deceptively charming Cornelius Williams of a "blue-blooded Knoxville lineage" proved to be a life choice that would plague her to the end of her days ("Columbus: Tennessee Williams"). 


\section{Cornelius}

Prone to barbaric mood swings and a dangerous addiction to alcohol, Cornelius wreaked havoc on the lives of Edwina, Rose, Tom, and Dakin (Edwina's youngest son). "[Cornelius] took no joy in the children, seeming to consider them just a nuisance" and Edwina struggled to give her children a happy childhood (E. Williams, 35). Children often get the wrong end of the stick about their parents, only taking into account how they were being affected when life's tragic events happened. But, I think with TGM, Williams was really looking at his situation through the lens of an adult. He knew that his mother was trapped in an abusive relationship and that "the Episcopal Church [was] strict...about divorce” (E. Williams, 39). Stanley Kowalski’s poker game in A Streetcar Named Desire was just the tip of the iceberg as far as what Edwina was put through in her married life. Cornelius cheated on Edwina repeatedly, and when she tried to exact control over the relationship, "Williams recalled hearing his mother's screams...as his father cornered her in the bedroom" because she would often "[withhold] sex as a punishment" (Jacob). This bit of information about the domestic abuse present in the household informed how I believe Amanda felt about her husband leaving. There was relief that she or her children would no longer be victims of an alcoholic rampage. However, desperation quickly took that sense of ease away. How would she be able to put food on the table? What had to be so hurtful to Amanda was the fact that her children looked up to the memory of her husband almost religiously, while she was probably the only one that remembers his true actions. She did all that she could to present a clean image of their father to her children. I think Edwina spent all of her energy dealing with Cornelius, too, and her anxiety just grew and grew over the years. 
Rose

Edwina's relationship with Rose in her memoir is described as being normal until Rose became a teenager and started acting out. This provided a lot of fodder for the imaginative backstory in TGM. I really tried to put myself in Amanda's shoes though the lens of Edwina. A lack of understanding of mental illness in conjunction with fear of the unknown led to the decision for Rose's lobotomy. Rose became too much for Edwina (without the support of Cornelius) to handle. Her mental illness is represented in the physical handicap of Laura, as well as Laura's agoraphobia and acute timidity. Amanda's inability to recognize the gravity of Laura's situation had to stem from the fact that Rose had a normal childhood—she was a happy, outgoing daughter and a best friend to her brother, Tom. It's difficult to realize that all of the plans a mother has for her child (who is perfect in her eyes) may never come to pass. There is denial, not out of malice, but in the sheer inability of Amanda to believe that Laura's problem is anything other than a lack of confidence, probably because the character of Laura as a child was happy and healthy. This shift into being afraid of the world had to happen at puberty when everything becomes muddled and confusing, right? She will get out of this really long phase. She must. This adds weight to the financial predicament engulfing the story of the Wingfields. What has to be done about Laura? I believe that Laura was a comfort to Amanda, because, "[though] Laura may not be able to physically take care of her mother in the future, it appears that she may be able to provide some moral support" (Janardanan, 35). Laura is the child that Amanda finds comfort in because her other child (who happens to be just like her in many ways) is extremely complicated. With Laura, at the very least, she gets respect to her face, while with Tom, she just gets the cold hard truth splashed in her face. This feeling of being more comfortable with one over the other would present itself very strongly in future rehearsals. 


\section{Looking for Amanda}

\section{Character Development}

This is the South, and we're proud of our crazy people. We don't hide them up in the attic. We bring 'em right down to the living room, and we show 'em off. See, no one in the South ever asks if you have crazy people in your family. They just ask what side they're on.

—Julia Sugarbaker, Designing Women, CBS (Hernandez)

It sounds pretty conceited to say that you just "get" a character right off the bat, and I cannot say that this happens very often for me-I performed the role of Charlotta from The Cherry Orchard at WVU and never had the slightest clue as to what to do with her-so I don't take this kind of inherent knowledge for granted. My background and my own sensibilities had a lot to do with how I came to know this character. Amanda is the quintessential aging Southern woman who is dissatisfied with her present because it doesn't hold a candle to the loving past she once had. She spends most of her time trying to correct this situation by planning for the future. Her characteristics obviously stem from a pleasant early life in the South from the days of privileged propriety, but her story is universal. How could you not know Amanda? Everyone can place someone from their lives in Amanda's shoes, which is why Williams' plays endure. This dysfunctional Wingfield family is a "part of America's fantasy," and the longing for bigger and better things is not only the goal of every human being, but the promise that is laid out for every American, even if it may only be a dangling carrot (E. Williams, 12).

I have some very strong female relatives that happen to be from the Deep South as am I. This is how I first connected to Amanda. When working on a role it's all about feeling it in the beginning versus filling your head full of facts. Another way I let my imagination start churning is through the designers' concepts. Designers see the character a certain way, as does the 
director, and other actors in the play, so everyone has a hand in shaping the character and getting it to production. Our costume designer had lovely sketches of how Amanda fit into Depression era St. Louis, and, of course, I was most excited about the famous cotillion dress (most especially because I got a laugh during the performances). That's the most poignant costume for Amanda because it brings a real piece of her past into the present, tangible proof of the life she once led. But, I found myself questioning just how good Amanda had it as a young woman because of her choice of husband. Was Cornelius in her mind really the pick of the litter? Was she really an old maid? Was life starting to pass her by? These ideas sprang to mind quite frankly because of how the character was being portrayed in the renderings. Amanda's cotillion dress, according to the rendering and the finished garment, had a paisley print, and had elastic at the waist. The dress needed to be functional as a quick-change outfit, but the color was definitely an interesting addition. Usually cotillion dresses are white. Perhaps they become a little yellowed over time. But, this 1970 s print was very interesting. It solidified the fact that my Amanda would definitely be embellishing her past. This was overdone; it was a bit gaudy. Fantastic, this could be used for comedic effect! The dress is usually a bit comedic just because it's Edwardian. But this print would really get some laughs. I ran with it! This outfit encapsulated her favorite memories and was a good luck charm for the evening, but also would show that Amanda has a very skewed perception of herself. Amanda's other dresses were very matronly and simple, and looked a bit outdated for the time period, just to reinforce how much they were financially at the end of their rope. There weren't any accessories except those for the cotillion dress - a barrette and earrings. The most fancy dress was, of course, the DAR dress complete with a hat and shabby coat. Looking on the inside and outside for Amanda at the same time, really helped solidify ideas for later rehearsals. 


\section{Two-Sided Grandmother: Personal Experience}

I only had the first twelve years of my life to size up my grandmother, Jean or "Maw Maw Warren," but what is always fresh in my mind is her undeniable charm, her ability to remain the center of attention at all times, and her amazing cooking skills. Of course, as I'm getting older I realize that her famous chicken soup was also served with a steaming side of guilt, and those gorgeous Bloody Mary glasses on display at one time weren't just for decoration. Truly, no one could manipulate or derail a nice family dinner like my grandmother. If drama wasn't taking place — just wait five minutes. She, like many other Southern women, were constant performers, having the ability to set the tone for a gathering, and expecting others to fall in line with their wishes. It's heads or tails whether the vivacious side or the scary side would be face up, but these women are truly a product of Southern culture. Stereotypes from film and theatre may brighten the colors, but the extensive, very real palette of emotions is ever-present. Gentility is the goal for the Southern household, but exacerbating deep-seeded issues is a way of life! And everyone from the North or South, East or West, can relate to the drama of a dysfunctional family. It's an American tradition!

Just like Amanda, my grandmother was forced into being a single parent, with all of the fear, anxiety, and increased responsibility that this type of situation breeds. Sink or swim, she was the only one who could make sure that her children would thrive in the world. An actor must share their character's point of view, and with all of Amanda's faults - the vise grip on her children, her disillusionment, and her desperate and horrifying matchmaking skills—I really couldn't judge her too harshly for what she was trying to do. From the outside looking in, Amanda is the personification of nails on a chalkboard. But, when taking into account just how terrifying the situation is where survival is questioned, (and that any hope for an escape is resting 
on the shoulders of two very misunderstood children who are quite frankly very useless), I began to see her side quite clearly. The incessant talking could be explained very easily—it's impolite to have dead air where I come from, and the truth is that if Amanda didn't talk, there would be complete silence in the Wingfield household! So, with Meisner's concept to start with the self, I suppose I used the memories of my grandmother and how I was affected. I then used a bit of Adler imagination to try to discern why she made the decisions she did. I've always believed that actor training is a grab bag — the situation shapes the technique — and Amanda Wingfield was definitely going to need a few different methods in order to get to the stage. 


\section{Shaping Sound and Facing Other Performances}

Later, when I wanted to "see and hear" Amanda more clearly for myself, I got some help from some very famous actors. Along with the personal connection that I found to Amanda, I also started choosing my ideas of how she might appear and sound at different times, and I drew those depictions from other actors that I admire, because as Stella Adler says, "You always steal as an actor [and] you can steal from life" and television and films are a huge part of my life (Adler, 239). My thoughts on how I wanted to deal with the moment-to-moment reactions that Amanda had and most of the actions of the play would come later in rehearsal. In the beginning, I needed to collect certain sounds and bits of physicality in order to have an idea of the shape that Amanda would eventually take. I wanted to get away from the "Scarlett O'Hara on acid" type of accent that most actors adopt for Williams' plays. I believe the British actors who portrayed Williams' characters in the legendary films made in the 1950s and 1960s were amazing, and their dialect work was wonderful. However, the sound that they created has been magnified and stereotyped in popular culture to such an extent that the Southern cadence can appear extremely overdramatic and indulgent. Molasses drips off of the sound, but no one can listen to it for very long without falling asleep. I tried to approach the dialect with a lighter touch.

Most actors might think that to watch others portray a role that you have been cast in is forbidden, probably because of the fear of being influenced. I disagree. In my opinion, to watch others in a role allows for a type of historical research in itself. It helped me to start a debate within myself about what I approved of and what I didn't for the character. No theatre student can get too far without seeing a production of TGM anyway, so one might as well just embrace the fact that others have done it well, and for very specific reasons. To choose not to take a closer look would have been a missed opportunity. I have accumulated many heroes in my "favorite 
actors" collection, drawing from television, the silver screen, and the stage. When I decided to pin down what sort of "vibe" I wanted Amanda to have, I turned to Joanne Woodward and Geraldine Page. These two magnificent actors had such grace and believability. The Williams' characters they portrayed never "chewed the scenery" or got lost in the theatricality of the Williams landscape. I wanted to soak up their genuineness.

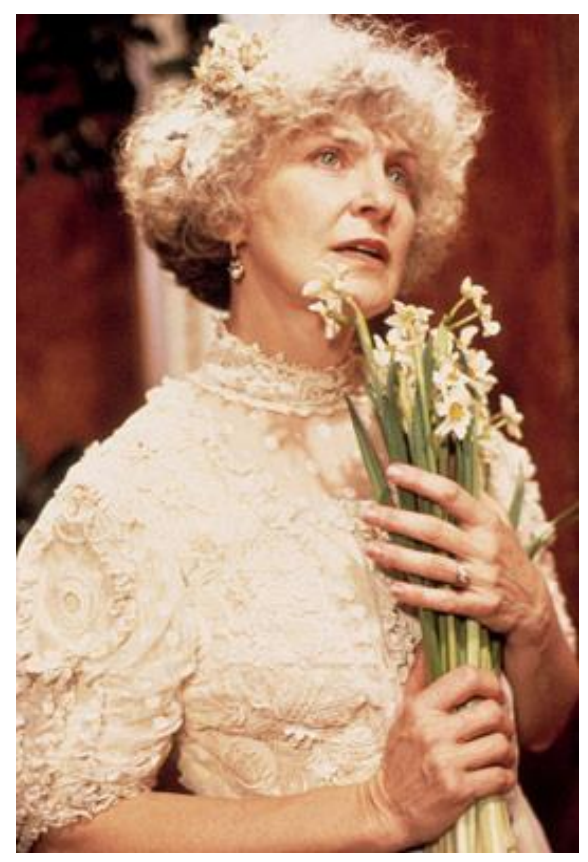

Fig. 8. Joanne Woodward as Amanda Wingfield, 1987 (film)

During high school I got my hands on a VHS copy of $T G M$ directed by Paul Newman, starring his lovely wife, Joanne Woodward. It isn't widely distributed and I could only watch a few clips online while I was doing my research, but her delicate accent is what I loved most about her very lovely performance. Originally from the Deep South, Joanne Woodward's melodic phrasing seems like a chirping bird, but also falls into her own particular vocal cadence: a languid rhythm with staccato touches here and there. She uses a lot of frontal placement and seems to have a chewing motion, which really signifies that she is "chewing the flavor" out of each word she utters. Woodward's Amanda loves to hear the sound of her own voice. There is no 
doubt that this character learned the art of elocution at some point, as an accomplished young woman would in the 1900s. Her Amanda is also very proud of her feminine Southern dialect sounds, and probably emphasizes it in places for effect.

Joanne Woodward's intelligence and sincerity are what I've always admired the most. Looking at parts of the film again, it is clear that her Actors Studio background enabled her to really ground this character. Also, given that her performance was for film, she didn't have to project too much with her actions. The camera met her halfway. Her Amanda was both very ethereal and forceful when needed.

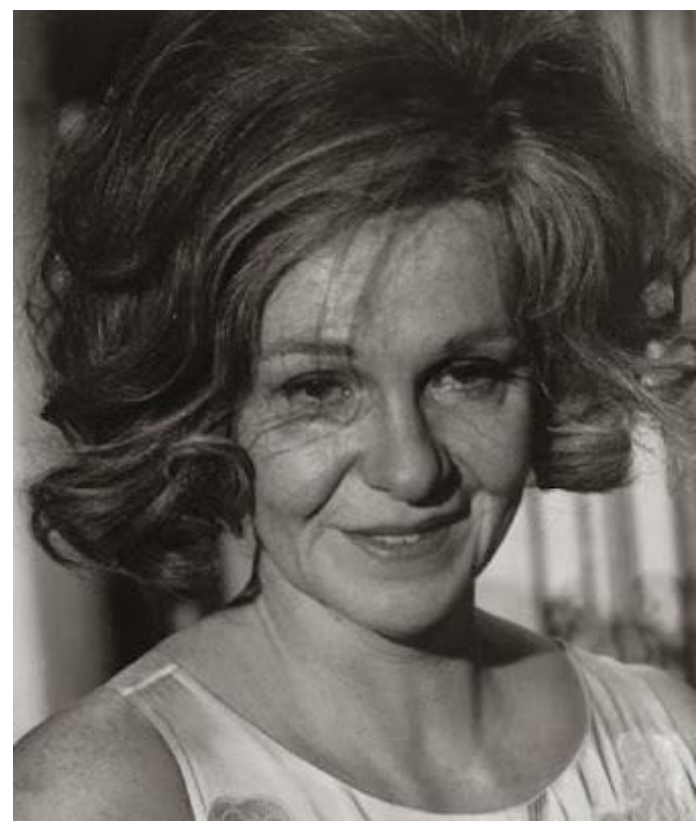

Fig. 9. Geraldine Page

Another actor known for Williams and other Southern dramas is Geraldine Page. She is not originally from the South, but from Missouri (which is helpful for Amanda as far as the play setting). Her drippy Southern dialect is spot-on in such films as Toys in the Attic and Summer and Smoke. She is all at once charming, annoying, grating, nasally, and child-like, which is pretty much in Amanda's zone! The nuance in her facial gestures that made her appear unattractive yet sympathetic — mostly how her lips widen into a smile when she speaks, content 
or upset, which squishes her very plump cheeks - and her ability to look frenetic yet serene at the same time is her own unique gift. Her squinty, matronly, and dowdy quality was something that I wanted to incorporate into the portrayal of Amanda. I don't look like her at all, but I thought Amanda should look like her. Page is fantastic at playing old maid characters because there's something about her speech pattern and vocal quality that reminds one of a stereotypical old maiden aunt who revels in cats and agoraphobia. The kind of self-pity that Page has as Alma in Summer and Smoke was useful to observe when having to navigate through Scene Four (the makeup scene after the big fight with Tom). Having to get to the point of tears each night always seemed to start out with the Geraldine Page widening of the mouth, a frown, and then a squint. It was funny that in order to try to cry like an older mother my face gravitated toward the "Page grimace."

Inside to outside, outside to inside-I've never used one particular technique of character development. Each character that I've played has had different needs. For Amanda, I would use both internal and external influences to try and understand her. She's a product of another time. She is removed from the current Depression-era setting in her imagination. Amanda faces reality and flees from it. She wants the best for her children, but also believes that she deserves more than her present circumstances have provided. Amanda is a complicated mixture of martyr, manipulator, and mother. Looking at resources helped me determine how others would see Amanda, and my own background helped me fill in the gaps. 


\section{Truth in Illusion}

\section{Plot Summary}

"Yes, I have tricks in my pocket, I have things up my sleeve," says Tom, playing the dual role of both narrator and a character, as he opens the show with a direct address to the audience. He explains that "the play is memory" and it concerns the life he once lead with his eccentric, overbearing mother Amanda, and his shy, enigmatic sister, Laura. They lived in a tenement apartment in Depression-era St. Louis. Tom speaks to the audience in the present while looking back at the home he left behind. The play is, in a sense, seen through Tom's eyes as he seeks a form of absolution by revisiting his own personal coming-of-age story. After he addresses the social background of the play—how American society seemed to be spinning its wheels while revolution was taking place elsewhere in the world-Tom joins the already poised Amanda and Laura at the dinner table. With hardly any goading at all, Amanda slips into a type of reverie-like performance for her children. She lists some of her favorite "gentlemen callers" who would often come to visit her in her very comfortable, dainty, beautiful little Southern world that she lived in. This brings to the forefront the fact that Amanda has a wistful longing for and very persistent attachment to the past. We see her way of coping with the present. Having been abandoned by her husband sixteen years prior, she and her family have struggled to make ends meet. With this kind of financial desperation, she in turn clings fiercely to her adult children, prompting them to better themselves to attain some sense of security. Amanda clears the table and gleefully asks Laura how many gentleman callers are due to arrive in her cheerful, hyperbolic manner. At the same time, Laura acknowledges to Tom that their mother fears that she will be an old maid.

Laura, much like her mother, lives in a dream world of sorts. She is unable to function in most social situations. Fraught with severe shyness due to her limp and subsequent low self- 
esteem, Laura clings to the things that bring her the most comfort: her father's old phonograph records and her prized possession, her glass menagerie - a collection of glass animal figurines. The glass menagerie, as the namesake of the play, represents the fragility of Laura, as well as the fragility of the family structure itself. The tension that underlies the entire play comes from the different needs of Tom, Laura, and Amanda. Tom longs to be a poet and to be free of the constraints of responsibility toward his mother and sister. Amanda wants security. The only way to have it is for Tom to keep his place as head of the family and for Laura to be taken care of in some way. Of course Laura longs to escape the realities of her predicament by hiding from the world, convinced that she has nothing special to offer.

The second scene opens with Laura dancing to the sounds of the phonograph as Amanda glides through the door, out of the cold, wintry air. She enters with a Joan Crawford-like performance over how aghast she feels to have just discovered that Laura has not been attending Rubicam's Business College, supposedly due to an embarrassing incident of "nervous indigestion." When Laura discusses how she was mortified and decided to roam the streets each day rather than confess, Amanda is at a loss as to what to do with her severely introverted daughter. After Amanda's initial anger about losing fifty dollars for the tuition subsides, she earnestly tries to explain their dire situation. Then, with exuberance, she jumps on the idea that if Laura could be married, their security would be set. Amanda asks if Laura ever fancied a boy, and Laura comes out of her shell. She tells Amanda about her old high school crush, Jim O’Connor-basically the quintessential all-American boy—who called her "Blue Roses" after she tried to explain that she had missed school due to a case of pleurosis. Suddenly elated about the idea of preparing Laura for gentleman callers, Amanda skips out while momentarily, Laura is left in a state of resignation. 
A few weeks pass and in Scene Three, Amanda now sells magazine subscriptions in order to help pay for Laura's "debut." A rude customer on the phone sends Amanda towards the dining room to nettle Tom, as he writes at the dinner table. A conflict quickly escalates to a shouting match as the two titans battle it out. Tom claims that he has nothing to call his own, reeling from the fact that Amanda went through his things. This in turn makes Amanda reveal how absolutely terrified she feels about what her son may be filling his head with. She confronts him, asking where he might be going at all hours of the night. She proceeds to try her best to shame him into not becoming like his father. As the argument reaches its zenith with Tom calling Amanda a "babbling, old witch" his coat knocks over one of Laura's prized glass animals. Amanda, hurt and bewildered, refuses to speak to him unless he apologizes and then swiftly exits. Tom, dejected, leaves the apartment for a night of drinking.

Scene Four opens with a very drunk Tom trying to let himself back into the apartment, waking up Laura in the process. As Laura tries to get him to calm down, he regales her with a far-fetched explanation of how he helped Malvolio the Magician at the movies, all in a very inebriated, jolly tone. This becomes a very touching moment between the brother and sister. As Tom finally winds down, time passes and immediately the alarm clock sounds accompanied by Amanda's shrill "Rise and Shine!" Amanda sends Laura on an errand so that she can talk to Tom. As Laura prepares to leave, she urges Tom to make up with Amanda. While hurrying out, Laura slips on the fire escape steps. This forces Amanda and Tom to acknowledge each other. Amanda waits for Tom to begin. As he gets out a very meager apology, Amanda delivers her apology as well, trying to make him understand how his mysterious ways send her into a nervous panic. After reconciling, Amanda gets to the point: Tom needs to find a nice young man at the warehouse for Laura. If he does, he can be free. Tom begrudgingly agrees as he heads out 
speedily for work, so as not to be late, and Amanda once again has enough peace of mind to get through the day.

A month or so passes. Scene Five opens on a leisurely spring evening. Amanda wanders out to the fire escape where Tom is smoking and they have a nice, easy, and loving conversation. This leads Tom into delivering some very good news indeed — there's going to be a gentleman caller, and he's coming tomorrow! After going from elation at the thought of a guest to the horror of not having the house prepared, Amanda goes with the flow and immediately starts asking questions and getting things in order. Tom tells her that the young man's name is Mr. O'Connor (and without a beat Amanda says she will prepare fish because the next day is Friday, and he's obviously Irish) and explains that he is a shipping clerk who takes night classes. Amanda, pleased as punch and prattling on, fails to realize how Laura will be affected by this dinner, and Tom warns her not to expect too much. Amanda, be it denial or wishful thinking, truly believes that this boy will be Laura's golden ticket, and she gleefully invites Laura outside to wish on the moon for happiness and good fortune as the lights come down on Act One.

Act Two opens up with Amanda putting the finishing touches on Laura's dress as they await the arrival of Mr. O’Connor. Excitedly, Amanda runs to the trunk and puts on her old cotillion dress, which just happened to be the dress that she wore for all of the happy memories of her youth. She glides through the apartment reliving those past days, and gets caught up in the reverie of meeting her husband for the first time, a bittersweet moment that snaps her out of her daydream and sends her back into preparation mode. Amanda hopes that Mr. O'Connor and Tom beat the rain leading Laura into a tailspin after she finds out that Mr. O'Connor's first name is Jim, her "Blue Roses" Jim! Laura immediately tries to get out of the dinner, feeling sick to her 
stomach, but as the two boys arrive, Amanda forces her into opening the door for them, which results in a very awkward Laura exiting while Tom and Jim have a talk on the fire escape.

Unbeknownst to Amanda, Tom has paid his dues to become a merchant marine with the money set aside to pay the electric bill. He plans on leaving home very soon. After a few more moments in the kitchen, Amanda prepares herself to meet Jim for the first time, and when she does, attacks him with fierce small talk while playing up Laura's good qualities. As Tom, Jim, and Amanda sit down to the table, Laura barely makes it into the room before she begins to faint. A horror-stricken Amanda tells Tom to lead Laura into the living room while she sheepishly tries to keep the evening going. As the lights go down on Scene Six, Amanda looks longingly at Laura during the saying of grace, praying for a miracle.

Scene Seven opens up during a highly successful dinner conversation full of goodnatured chatter when suddenly the lights go out. As Amanda leads Jim into the kitchen with the candelabrum to help with the fuse, she discovers that Tom has negligently forgotten to pay the bill, but recovers from this upset by convincing Jim to go and keep Laura company while making Tom conveniently help her with the dishes as a punishment. Jim and Laura begin a tentative conversation by candlelight about life and reminisce about their old high school days. This has become one of the most iconic Williams scenes in his entire canon. Laura confesses to being extremely self-conscious about her limp, which has made her afraid of life. Jim, much like an exuberant cheerleader, tells her that she has to believe in herself. Enchanting mood music from the dancehall leads Jim to ask Laura for a waltz. They dance around until suddenly Jim knocks over Laura's favorite glass unicorn on the table, which she had been showing to Jim. After a few awkward moments, Jim finds himself drawn to Laura and kisses her, but immediately pulls himself away. The rug is pulled out from under Laura when Jim tells her that he has been going 
steady with a girl named Betty, quickly trying to dig himself out of the hole he has made. Dejectedly, Laura offers him the unicorn as a sort of souvenir as Amanda sweeps excitedly back in with lemonade. Jim tells her that he must be going and when she tries to make plans for another get-together, Jim tells a very stricken Amanda that he is going to be married soon and quickly leaves. Believing that Tom knew that he was engaged the entire time just to spite her, she yells for him to come out of the kitchen and completely falls apart, screaming at him ("Go then, go to the moon you selfish dreamer!") This fierce confrontation provokes Tom to leave for good. The final moment of the play ends with Tom telling the audience that he went further than the moon because "time is the longest distance between two places." In a final close to his story he gravely says, "Blow out your candles, Laura," which extinguishes the memory. 


\section{Rehearsal Process}

The Line Challenge

Amanda never stops talking! Going into the rehearsal process, I was already having those actor dreams - the ones where you're performing for the Obamas, but you have no idea what the play is or what the lines are, and there's more than one play and if you disappoint President Obama you'll be shipped off to Russia. Sure, we all have them. It never fails, no matter how much I know that being able to memorize pages of dialogue is not the actor's only aim, getting lines down will always be the part of the process that concerns me the most. Thank goodness for my nerdy need to test myself by writing cue lines and recording them as well.

Apparently, it has become a trend in the world of theatre for actors to come to the first read through off-book. That does sound wonderful when thinking of the big picture of getting a play on its feet, but it just sends me into a panic. I guess I got into the habit a long time ago of getting off-book during blocking — studying up on lines before and after rehearsal in order to get the lines into my body. I always try to get off-book during the first or second week anyway, well before the stage manager's deadline, because it is nice to start worrying about other things. But, since I had the winter break to start tackling Amanda's monologues one by one, I felt that I was losing time to get the research done. Having to show up to the first read-through off-book added a lot of pressure. I was off-book for the first four scenes by the time our first read-through rolled around on Monday, January 27 in the Falbo Theatre. Luckily, it was all right — at least I think so - that I was only partially memorized, and the read-through was mostly about the meet and greet and discussing the context of the play. 


\section{Improvisations}

After the read-through, the first manner in which we really started to dive into the play was with improvisations on January 29 and 30. Since TGM is told through the smoky atmosphere of a memory, and is basically a string of vignettes in time, Kathleen Amshoff, our guest director, wanted us to start playing with the back-story of each scene, whether it was years in the past, or merely the more immediate fillers from scene to scene. I loved this idea and thought that it was very important, but usually doing improv gives me an ulcer. I love when I get to watch others improvise, it's just I've always found the pressure to be funny and clever within nanoseconds while trying to continue a narrative where there's no endpoint to be really taxing. I love getting laughs, but I enjoy knowing what I'm supposed to be doing, even if it's just a skeleton script. Just going with the flow in this manner gets on my nerves. You always feel you have to be doing something or it's your fault that the story falls flat. But, in this atmosphere where there wasn't an audience and you can have bits of discovery in your own time, it was an ideal situation.

My favorite storyline that we had was Amanda as a young woman meeting the gentleman callers on the porch. I was kept out in the hallway while Kathleen and our stage manager set up the room, complete with lighting and Appalachian music. This was the easiest one for me. I just entertained the two guys as they came up, and ended up waltzing with the actor playing Jim, who also was having a good time with the silliness of it all. Getting into the excited hostess mindset was very easy. Being bubbly Amanda was going to be a lot of fun. But, oh, those manipulation and desperation layers, well, we would get to that later. 


\section{Lovely Children}

After watching the actors playing Laura and Tom go through an improvisation where they were small children playing with the glass menagerie, Kathleen gave me a prompt to go under their little tent they had made and tell them that their father was gone for good. Ah! That's so terrible! I didn't want to do that, but of course, that's what Amanda had to do, so fine. That's very heavy stuff. I crawled under the heavy blanket, which quickly turned up the temperature from 80 degrees into 100 in a matter of seconds and tried very tentatively to tell them that their father was gone. Now of course, I was met with things like "Get out, Mom," "We're playing," “Go away, Mom," "Why are you disturbing us, Mom?," "Why don’t you go fix dinner, Mom?" which made me think how I wanted to drag the actors out and start pelting them with pillows because they were being difficult on purpose, first Tom and then following suit like a little puppy, Laura. It felt to me that the actor playing Tom was putting up roadblocks in the conversation because of his need to prove himself in front of Kathleen. As a result, I was met with a lot of 'No' instead of the proverbial improv 'Yes.' It seemed quite apparent to me that he had been trying to throw me under the bus during this whole process. Although I knew what he was doing (the minute he was cast I knew what I was in for), it didn't mean that after a long day of being in the theatre building and then settling into a long rehearsal in a boiling hot room that I was in the mood to contend with him. Is it normal for Amanda to want to throw her children out the window? Good grief, they both were so annoying in this exercise. But, then I thought, of course, even though the real children wouldn't be this hateful (they wouldn't—-they're still small enough to have those manners I taught them) I'm still trying to explain a very life-changing situation to two children. Amanda has no one to talk to. That's an extremely lonely place to be in, and I don't think she ever truly gets a reprieve from that sense of isolation. And perhaps her 
incessant babbling is because silence would bring about too much of an opportunity for self-pity and self-awareness. Talking, talking, talking, ever-moving forward is the way to go, because there is no other option.

Another enlightening improvisatory moment came when Laura asked when her father would be home, and I replied, "I'm not sure, but maybe you should keep the glass menagerie clean for when he comes back." Where did that come from? How awful to give a child false hope, and yet it tied her little obsession with the glass menagerie up in a bow, for me at least. You really are limited when you're talking with children, and in this little scenario, her children are already little brats, so I feel very sorry about this moment in Amanda's life. Her children already find her annoying and don't want to be around her. Ungrateful children, just like their father! Another telling improvisation was the situation of a young Tom, ill and in bed. Amanda reads to him. The book quickly became a western adventure, and hopefully this helped give one reason for Tom's fascination with far-off places.

The scenario that was the most uncomfortable for everyone involved was Laura getting her period. In the Falbo Theatre, there is a sectioned off spot upstage where the actor playing Laura and I could go hide out as I tried to explain to her what was going on. Halfway through it, Laura and I just stopped, giggled, and really thought about the fact that since we were behind the wall, as it were, we could just hang out for a bit. This was getting silly, and in the 1920s a mother wouldn't explain the whole enchilada about sex, all the birds and the bees, so it was a lot of prattling nonsense. It did make me aware just how much closer Amanda could be to Laura than Tom. Then, of course, Tom and Jim came to the apartment and it was a farce of trying to hide Laura and make excuses, and more stonewalling from Tom. I wanted this one to be finished 
quickly. Waltzing was a lot more fun than trying to guess what feminine hygiene products were like in the 1920s!

After these few luxurious rehearsals of just playing around with character back-stories and talking about relationships, we started blocking the show. We had already gone about the business of creating memories. Now, we just had to deal with how those back-stories would influence the present. It was nice to have some warm moments to take refuge in because there were some very rocky situations that had to be dealt with in the world of the play. I love getting the blocking out of the way early; it's a very helpful part of the memorization process. We had a rough sketch of where we were supposed to be, and this helped tremendously once we dived into off-book rehearsals. 


\section{Monologue Sinkholes}

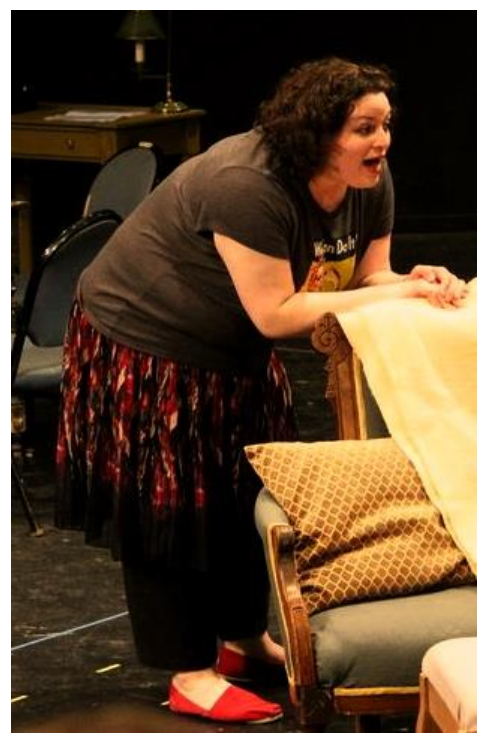

Fig. 10 Off-book rehearsal, Scene One.

In the final episode of the first season of the Canadian television series Slings and Arrows entitled "Playing the Swan" there is a scene where the director is coaching a very timid actor playing Hamlet from the wings during a performance, reassuring him that Hamlet goes through six major soliloquies, ticking them off one by one as the very nauseated young man rises to each challenge (Wellington, Slings and Arrows). In no way is the character of Amanda as exhausting as playing Hamlet, but I often found myself laughing about how many monologues Amanda had, and how at each rehearsal (and subsequently each performance) I would mentally check each one off with relish, knowing we were moving right along. In my mind I was saying, "Oh, good, the Rubicam's speech is over, it's almost time to fight," or "Thank God that spiel about Tom turning into his father is over, just one more scene and then on to the very fun gentleman caller dinner," etc. I truly have no interest in doing long monologues, and I suppose I'm not supposed to admit that because, shouldn't every actor yearn for that kind of time in the limelight? As a character actor and lifelong fan of Carol Burnett, I always shared her belief that one shouldn't wear out their welcome on stage. I'm used to darting around a bit, going off for a while, and then coming 
back, and I suppose I always had the fear of not wanting to be too taxing to an audience. Well, with this role, it was inevitable. And each monologue, to me, felt like I was holding up the momentum of the show. Everything would be clicking and then I would have to get caught in a sinkhole filled with gentlemen callers or jonquils! Knowing that we were obviously going to be playing to obligatory student audiences, I braced myself for the fact that I was probably going to bore some people to tears. But I was determined to try my best to drive those monologues, and try my best to keep the pace up so the process would be as painless as possible.

Most of my notes from Kathleen had to do with the monologues which I named:

"Gentlemen Callers," "Rubicam's," "Jonquils," “Attack Jim," and "To the Moon." On Saturday, February 8, I had a monologue workshop with Kathleen and we covered "Gentlemen Callers" and "Rubicam's." For "Gentlemen Callers," the notes concerned my need to make the dining room my playing space and become very theatrical with the delivery, because in a sense I was performing for my children. Little bits of humor were kept, like being catty about Bates having my picture on him the night he died, and how he never loved his wife as much as he loved me. Specificity was an issue with this one because it was so flighty and just moved from one man to the other. I rushed through it because, much like "Jonquils" it was just very awkward, with very little true interaction with the others on stage, especially since I was upstage of Tom and downstage of Laura. The set was really difficult to navigate, and it was hard to feel comfortable being so vastly upstage on a raft-like platform in the abyss. I never felt connected to anyone during these diatribes because of the need to create stage pictures on the very compartmentalized set. One manner in which I did learn to cope with this flighty monologue was by listening to the underscoring chosen by the sound designer Professor Alan McEwen (only to have it cut a few weeks before technical rehearsals). I connected with "The Lover's Waltz," a nostalgic tune with 
a wonderfully sympathetic melody played by violins. I could really fall into that dreamy, longing sort of pace with the help of that music. But, since I didn't have it during the performance and all of my notes differed from what I got from that piece of music, I just had to plow through it as best as I could. I had to hit a certain corner of the platform at a certain time. I tried my best.

For “Rubicam's," I felt like a really bad Joan Crawford impersonator. The intention took a direction that I really didn't agree with: I wanted to be a bit more put out about the fact that we had just lost most of Tom's monthly wage because Laura was too timid to confess that she no longer attended business college. I had a feeling of dejection when I earnestly asked her, "So, what are we going to do the rest of our lives?" Kathleen wanted me to somehow keep it more upbeat, which I supposed worked for the big-picture pace of the show, but I just felt like I was faking it. Amanda is hurt and so disappointed, that switching into "Plan B mode" so quickly didn't feel right. It's almost like I needed more time as the character to hatch that plan. But, since Kathleen wanted me to "think up" I "thought up," but I always felt that I could have done the monologue better if I had the ability to reach rock bottom before picking myself up instead of going straight into Kathleen's idea of manipulation straight away. Would Amanda make a point of manipulating, or does that mother's guilt just become an inherent part of everyday life? I felt that by purposely manipulating Laura, and playing that action I suppose I was fulfilling Kathleen's need for me to be a bit nastier with Amanda to provide a different level, but I always felt I was glossing over a moment that had a lot more depth to it.

I always thought that the play wouldn't miss much if my rambling diatribes were cut a bit. The play could get down to an hour and a half if some of my monologues were trimmed, or cut completely! I wasn't too fond of most of them, but the "jonquils" reverie really took the cake. 
She's giddy, then rambling, then giddy again, then lost in reverie, then awkwardly silent, all while saying “jonquils" ten million times! And I'm not alone in my views:

Laurette [Taylor] objected because in one scene the word "jonquils" appeared a dozen or so times within the space of a few minutes. "It sounds like too many jonquils to me," she said. "Can't you cut out a few jonquils, Tennessee?"

"Laurette," Tom said, "it's got rhythm. I need all those jonquils." (E. Williams, 149)

No, but really — there are too many jonquils in this speech. I never got the rhythm down, never got the emotional depth, never hit it just right, or if I did maybe in one odd rehearsal, I never got it during a performance. Either I would linger too long in the reverie about the father and not "earn it" or I would not give the moment enough gravitas in some other way.

I tried looking at images of jonquils, fields of jonquils, which usually helps me, but to no avail. I played for the laughs on this one, because the speech is just ridiculous, and I was told many times that I was commenting on Amanda. Of course I was, this broad was absolutely batty at this point, just so excited about the dinner, and completely making it about herself! I tried to endow the jonquils as a good luck charm, I tried really pretending I thought I looked pretty, when in fact I had looked in a mirror and knew that I looked comical for a reason-frumpy with a purpose. Whenever this monologue was over during the performances I knew that I had just one more to go before I got to go have a little break while Jim and Laura had their lovely scene!

Oh, the "Attack Jim" monologue was crazy! Amanda absolutely blows a gasket when Jim comes through the door, immediately showing that she has extremely nervous energy and is also out of practice when it comes to the conversational arts-a Southern woman's ability to talk to a brick wall. Kathleen wanted me to speed through it, and luckily, Professor Hitt told me that I 
should embellish the Southern dialect a bit more for Jim's benefit, which was hilarious! It was a huge kind of two-part monologue, and I was absolutely exhausted by the time I had to accost Jim on the couch about his tribulations and then without waiting for an answer bellow to Tom who was in the kitchen. Kathleen gave me notes about being more specific about letting him know exactly how much of a catch Laura was, and how lucky he was to get to meet such an accomplished young lady. I probably had the most fun with this monologue because it really was farcical in nature, and we usually got some laughs in rehearsals, and also in the performances. Act Two was my favorite because of moments like these.

By the time the performances rolled around, I just tried to find the humor in Amanda's speeches in order to earn the last moment of the play where she tells Tom to go to the moon. I always cried just thinking about that moment. That's the big moment. That moment can't be missed. In order to get there, I held out hope the entire time that Jim was working out, until he finally says the name, Betty. That was the final straw, and the fact is that I as Amanda believed that Tom knew the whole time. It was so painful. I felt that this moment always worked until Kathleen told me during tech to stop crying so that people would look at the actor playing Tom on the fire escape. Sure, you want me to have a nervous breakdown, but then I can't make a slight noise, not even a sniffle? I tried my best, but I was crying so much that I had to breathe! Later I found out that she had to tell the lighting designer to take the lights down on the actor playing Laura and I as we embraced because we were crying too loud and not letting the audience have their moment to feel the pain. I knew the focus needed to be on Tom. Well, I tried every night to tone it down, but at the end of the "To the Moon" monologue I was absolutely exhausted and I couldn't hold back the sound of my sobs. I fully understand that the silence was to illustrate the idea of a memory slowly fading away, but I had to sniffle in order to breathe. As 
Amanda, I had to come back in and look at my daughter who had just had her entire dream world ripped apart—and it was my fault. I'm not made of stone!

In the end, I knew when the monologues were landing and when they were just nonsense. I'm sure that I commented on Amanda's actions far too often, but it's because her ramblings are silly. I went toward the comedic to try and salvage the longer, more drawn-out sections. An actor always feels the audience and knows what works and what doesn't, in the moment. If I have any strength at all, it lies in comedy, and though I didn't set out to have a different take on Amanda just for the sake of it, I felt that she was a performer in her own right, and that she had to be charming. The only way I know how to be charming is to be funny. 


\section{Can You Hear Me Now?}

Professor Laura Hitt, our vocal coach, was at our first read-through and was pretty pleased with where my starting point for Amanda was. It helped that she knew how much of a fanatic I am for collecting sound bytes for character study. I felt confident that I was heading in the right direction. A lot of my questions for mixing Page and Woodward speech patterns arose because I had this idea that I wanted to be more truthful to the sound and not be Ma Kettle.

Once we were having rough run-throughs of both acts, Laura attended rehearsals for notes and coaching sessions. I love individual coaching sessions, probably because it reminds me of being with a personal trainer. You are getting a tailor-made program from someone who is committed to giving you the tools to reach your goal. A big part of my problem with some of the intense moments was that my physical alignment was askew. Due to the way blocking has to be on a $3 / 4$ thrust stage, there are so many points of distance in scenes, pretty much in a triangle shape, that we had to hit specifically for sightlines. Truth be told, I never felt like that set was my home - be it the levels or weird pointy platforms on which I had to hit certain arbitrary marks even though it didn't feel natural at all—it was really difficult to navigate, so I suppose my body fought against it with this sort of incessant clawing motion. During moments of vocal intensity, I wanted to bend forward, probably because I naturally wanted to be closer to the person I was yelling at, because getting in their face seemed more natural. But what it really looked like when I bent forward was an old crone reaching out to children to come into her cottage made of candy. It was a majorly bad habit that I needed to break. Amanda wouldn't stand like this; Amanda has too much pride to let herself get that out of control physically. She's a lady, to the very end. Not only does the character not carry herself that way, but bending forward made me go into another habit of mine: "crunch neck" or "computer neck." Whether it was from wearing bifocals when I 
was younger, or just one of those things, I have a tendency to jut my chin forward, raise my head and crunch the back of my neck, as if I'm trying to look through the bottom of my glasses, but I do it even when I wear contacts! For vocal dynamics, this blocks the open channel and also inhibits the scapulae when taking in air because of increased shoulder tension.

During my session with Laura, we discussed the "To the Moon" moment. As I was going through it, Laura put her hands on my shoulders to relax me, and then put one hand on my forehead as I went through the speech, primarily landing on those last words, "Go then, go to the moon, you selfish dreamer!" I remember having the image of a rocket as I elongated "moooon" and felt the energy going up and out instead of trying to shoot it right at Tom. My new found alignment really helped get me to that moment, and I tried my best to maintain that sense of going up and out during performances.

My other vocal notes were pretty much where my other habits lie: I get into a punchy rhythm with consonants in big monologues, I tend to get a bit quick with the language and lose clarity, I drop the ends of lines due to lack of vocal energy, and words with ' $\mathrm{q}$ ' in them: “inquiries" and "jonquils," primarily, forget about it! I was getting tongue-tied with the 'q' sound, so I had to slow down and jump up on top of them. In a sense, I pictured the sessions from the film The King's Speech the entire time, because for me there's always a film montage for every predicament. Working through these vocal notes, all I can say is that I tried to hit every note that I had coming at me, but if I missed some, or backtracked it was due to late night rehearsal fatigue.

I felt that Laura was pleased with the changes I made with my alignment and lengthening, but, not to use the set as an excuse (again) there weren't any flats to aid in sound production. As we got more and more into the runs it became so apparent just how much not having anything at 
the proscenium to bounce sound off made this process extremely difficult. I tried to keep my volume up, but there are times, if it's a more intimate, emotional section of a scene, that I guess I was aiming for believability and of course it was at the sacrifice of volume. The set was lovely, but not the most functional for being heard. I think as actors in that space, we depend on a little backing to have something to work off of, because even trying to hear myself sometimes I felt like Charlie Brown's teacher. But, all in all, I think knowing that I needed to have more vocal energy helped keep my momentum up the entire time. I had a constant awareness of sound, probably more than any other production I've done before. The set really became a rewarding challenge to me as a student actor to really use my entire body to support sound, and also to learn to trust that my vocal training thus far had made me capable of utilizing this environment. 


\section{Walking on Broken Glass}

People are different. Personalities don't always mesh. I'm an adult. I've known this for a very long time; yet, I have the hardest time accepting that. If I didn't mention the personal conflict that I had in my work with another actor (which overshadowed the initial rehearsal process and, quite frankly, made this one of the worst offstage experiences I've had with a show), I would be omitting a huge fact. This fact influenced most of my decisions on stage, but on a positive note, made me feel even stronger as an actor once the entire experience was put to rest.

I've believed in ensemble-based acting from the first time I stepped on the stage, even before I knew what it was exactly. Our graduate program is steeped in Meisner Technique, where all of your impulses and inspiration stem from a scene partner. Fantastic; everything I need to do my job comes from the other person, and vice versa. There's nothing better when it comes to being truthful on stage. I enjoy working with other people- the comfort that comes from another person being up there onstage, knowing that someone is there for you if something spontaneously combusts - because no one can act alone. Acting is a privilege because of the company you get to keep. It is not a competition; a story on stage is only believable when the people altogether on stage are on the same page. Acting in a vacuum is not an option, and yet, unfortunately, it can sometimes become the only option you have, besides breaking a contract. Not to color the whole experience with negativity, but there were some rehearsals where truthfully I felt that I was hung out to dry, and had to start pretending that I was getting what I needed from the actor playing Tom, something besides intense anger and stonewalling. I had to use my imagination.

I couldn't respond to Tom. This was made quite clear to me one night after a run-through 
when Kathleen turned to me and said, "You know you love each other, right?" My immediate, though internal, response was, "Lady, why are you looking at $m e$ ? Look at that angry brick wall I have to talk to, I've been doing everything I can to pretend that I love him, because pretending is all you're going to get!' But of course, I did the polite thing and used the excuse that because I'm an only child I don't really understand about parents having favorites when there are two or more children or some such nonsense. (Boy, I did everything I could to not come apart at the seams! Oh, I had a lot to discuss with my confidantes later that night! Oh, Holy Moses!) We ran the scene again and I just decided to cry in the middle of it, or "fake it." I can cry on cue-it's a power that I never use for evil, but it is an asset. She wanted me to love him. "OK," I said to myself, "I'll just cry so we can get out of here." After we finished the scene Kathleen said she loved it. Great, I'll just cry. It was nice to be able to check that off the list when I really wasn't in the mood to explore that moment any further!

The big, huge problem that could have squashed all of the other tiny inconveniences was the fact that Amanda and Tom had no relationship because the two actors playing them could barely speak to each other offstage. Amanda and Tom love each other; they are quite similar in many ways, which means that they are going to squabble, but there are just as many times when they should be able to make each other laugh, share inside jokes, and break up tense situations. That never happened. I kept hoping that Kathleen might notice the fact that as soon as we were done with rehearsals we avoided each other like the plague, or the fact that I was being accused of not having my lines in order when (not to toot my horn, but the stage manager said so) I was doing just fine. But, no, we never had a meeting, never had a heart-to-heart, and quite frankly I felt that I wasn't given a lot of time from Kathleen at certain points. I only had one meeting with her, while others had two or three. That's fantastic if she felt that I didn't need intensive 
direction. But, still, being made to feel like some background character is an issue. Even so, we all must stumble along.

Because my relationship was lacking with the actor playing Tom, I think that drew me, as the actor, into a better relationship with Laura. Though at first the actor playing Laura followed Tom's suit and bristled at a lot of Amanda's actions, over the course of the rehearsal process we had a great working relationship. The actor playing Laura was very shy and timid, and insightful, so of course the role fit her like a glove. I felt such sympathy for the character of Laura because I think due to her ailment when she was younger (I believed that she had a brush with Polio) and this accompanying social disorder, she was caught in a time period where no one could really help her or understand what she was going through. Amanda honestly thinks she just needs a little boost in confidence, when today she would be in intensive therapy. So, developing a relationship with Laura (my favorite child) was very easy and happened very naturally, while the relationship with the actor playing Tom remained very complicated, which in retrospect, seeing as how dysfunction is Tennessee Williams' defining piece of artistry—we definitely used that aspect to our advantage. It's the family members who are fundamentally alike that seem to have the most friction, and I believe this was the case for both sets: Edwina and Tennessee, Amanda and Tom.

Out of the "like a knife stabbing me between the eyes" frustration, I began to settle upon a solution after looking into what Stella Adler would say on such an occasion in The Art of Acting, her book of lectures compiled by Howard Kissel, and found, "When you speak to somebody, whether it's another actor on stage or that little old lady in the balcony, the most important thing is to make them see. Communication is making someone else see what you see" (Adler, Art of Acting, 36-37). Lovely! Long time no see, Stella Adler. I love Stella! 
Forever an Adler convert, I picked up where I had left off at The Stella Adler Studio in New York. I was not going to be pushed into overacting, which was the trap that was being set for me. I just had to tell this other actor pretending to be my son what I knew to be true and pretend that in Amanda's mind it was getting through, because I can admit that in my frustration with the process of working the scenes I was putting up defensive walls, too, and in the grand scheme of things, who cares about who started what or if the blame game is played out to a resolution? There was never going to be any sort of justice, and now that I've taken some time away from the process, I can see that if any part of this struggle had been changed for my personal benefit, there wouldn't have been anything from which to grow and certainly not as much to reflect on in this thesis. The shoddy rehearsals that made me want to scream just didn't matter anymore because slowly we were moving into a state where the saying of a script aloud magically becomes a play. There was a job to do, and I knew what I had to do-make myself believe that I could trust him and try to hold up that premise for Kathleen's sake and for the rest of the cast. And in time, trying to convince myself that I wasn't going to be left hanging, there sprouted a functional working relationship by the time we made it to the crew view and subsequently, technical rehearsals and performances. There had to be trust-it never was the kind of trust that I feel like every actor deserves — but it was a mutually beneficial trust that seemed to just barely cover the both of us. As comfortable as I was becoming with Meisner Technique in my classes where the pressure was off and the responsibility rested in feeding off of my partner, I had to go back to a place where I created the energy for myself, and I had that feeling when I studied at the Stella Adler Studio. Her technique inspires a specific type of leadership without stealing focus away from one's partner, and lights a fire in the imagination in order to be a force in doing something to your partner to inspire them and make them see your 
point of view. I had to get over the stress I was feeling, and pay attention to her wise words:

Critical seeing, self-awareness, discipline and self-control—-these are the demands we'll be working on. But none of these, once mastered, will matter at all without the energy. You must develop the energy necessary for the stage. You have to work for it. God doesn't just give it to you. (Adler, Art of Acting, 27)

This fiery old broad was just the coach I needed. Though I would continue to complain to confidantes throughout the rest of the process, her fierceness stuck with me. I needed to tap into a very special energy reserve. I had to get back out there and work! 


\section{Center and Go}

\section{Performance}

Even though rehearsals may not have been quite the party that I wanted them to be, the performances were probably the most comfortable I have ever felt on stage. The only other role I can compare it to is Mrs. Savage in The Curious Savage at Middle Tennessee State University, as far as stage time. I was comfortable back then, and had a great time, but gaining even more experience for this go-around, I really felt like all of my stage experience so far was really helping me to get somewhere with the performance. That sense that I had a job to do, which usually relaxes me and makes me capable of doing anything onstage (no matter how silly) became even more engrained because I knew there was nothing else that I would rather be doing. Every night right when I heard the music that meant Tom had hit the stage, it was "go time" and I felt very lucky to be doing this show.

With the addition of dressers and crewmembers, a lovely sense of camaraderie was established. From pre-show sing-a-longs in the dressing room to the quick changes with the swift professionalism of a pit crew, our dressers were fantastic. I loved the atmosphere of this show once we moved into tech rehearsals and performances. To be honest, I ticked off each performance on the tech schedule with relish after I got back to the dressing room. (It was a relief to get closer to the end no matter how enjoyable the actual performing of the show was because this was an "extraordinary" experience to say the least). But, I believe including the crew and costumers was a great way to diffuse the tension, and of course, once we were in performance, we all felt the luxury of just trusting that all of the strenuous rehearsals had paid off.

Getting into costume was a nice routine, and I've always found the "getting ready" process to be very relaxing. I'm usually the first actor to arrive, and I like taking my time, 
listening to music, and chatting with everybody. Donning the costume of Amanda was interesting for the first time because so much of Amanda's personality is dependent upon her keeping up her appearance even if she's wearing old clothes, even if her accessories are antiquated, because she's a woman that knows how to put herself together. I never felt that the dresses fit me properly. It's difficult designing for a big woman; no costume designer relishes the fact that suddenly they have a million different things to worry about as far as patterning and achieving their design aesthetic at the same time. I've come to terms with my weight, but I know when I'm not wearing a flattering costume, especially when I'm supposed to look dignified. My undergarment one-piece didn't have an underwire in it, and since I was fitted with just that on, I couldn't wear any of my own clothes underneath it, so I felt like I was flapping in the breeze, so to speak, without an underwire! It affected my posture, how Amanda walked, and the mannerisms, and I just never felt like the idea that I had of what Amanda should look like synched up with what I was given. If the costume designer approved it and Kathleen gave the goahead as well, I had to learn to be fine with it, too. Which, I did. I used everything I had to get some laughs into the show, and my appearance became my main weapon of choice. But, in my honest opinion-Amanda should not have looked so haphazard. She is a woman who knows how to put herself together. It's difficult to fight that feeling that the outside does not represent what is going on internally. But, that's really not my department, and getting a character onstage is truly a collaborative effort.

There was a sense of calm before each production. I never really had a checklist in my head of hurdles that I had to jump over, or fear of the emotional journey. Surprisingly, getting through the play wasn't a burden (just the rehearsals). All I had to do was put my hand on my stomach before the show began, and I knew that everything I needed to do the part was there 
with me already. A lot of my training at WVU has really made me understand the concept of having the text "in the body." I believe this feeling must be indicative of the fact that I have grown in confidence as an actor. I can trust myself better than I did about seven years ago when I was cast in my first show. I've thought of myself as a late bloomer for not discovering theatre until my twenties, but perhaps, everything happens for a reason. One positive stage experience led to the next.

I connected into a certain rhythm on stage and never felt lost. I had a kinesthetic response to the material from early on because of the environment of the play found in the text, and that came in handy in a very stark playing space. I knew when the audience was bored and I could keep going, while mentally telling them, "Hold on, Act Two is a lot more fun." Scene Four and Five just dragged so much, I could tell when we were losing people, but that didn't matter. I had words to say that were no longer in my head, they were in my body, and every night I felt ready for the rollercoaster that was this show. I didn't have much difficulty reaching the emotional peak of the show; I just tried to hold on to hope that Jim would really work out for Laura — until I could hold out no longer. Then pent up rage and frustration just came pouring out. The final moment between Amanda and Tom was something that I had been imagining from the time I was cast, and I always felt that Tom was completely in the wrong. It was totally his fault. He had to have known that Jim was engaged! Of course, from an audience member's perspective, he probably didn't know about Betty, but his inability to give a damn, well that was enough to send me through the roof! Either way, whether I chose to believe him or not, I pretty much had the same breakdown. Amanda's such a mess!

Technical aspects of the play were very amusing. Some nights the fog was a bit thick and I had to walk right through it, thick as soup. Sometimes the candles were too long and they 
would blow out resulting in a quick impromptu to Jim, “Oh, Lordy, they blew out didn't they? Could you light them again for me, honey?" Going behind the masking that was too close to the wall with the candles was always ridiculously funny. The actor playing Jim and I said our offstage lines while our assistant stage manager was waiting with a fire extinguisher two inches away. We often included her in the scene just to amuse ourselves. I thought surely we would have to move the masking further out during tech rehearsals, but no, we just had to squeeze through and pray. I was just glad that I didn't trip going down the escape steps with those candles because it was so dark, and of course, I'm glad that nothing was set on fire, which is always a plus. TGM is the most prop-heavy show I've ever done, and it's ironic because it's a memory play with a certain amount of miming — no drinks, no food — and yet it became so much about the props! There was always the hope that the glass animals would break in the right way and the candles would behave themselves. It really kept us alive onstage the entire time! 


\section{So, Sue Me—I'm Sensitive}

\section{Personal Conclusion}

The life of an artist is not a state of 'being.' It even sounds pretentious, sometimes, to call oneself blanketly, 'an artist.' A doctor becomes a doctor because he or she is formally given an MD...We are on the fringe, and we don't get such licenses. There are prizes and rewards, popularity and good or bad press. But you have to be your own judge. What you are will show, ultimately. Start now, every day, becoming, in your actions, your regular actions, what you would like to become in the bigger scheme of things. (Smith, 34-37)

-Anna Deavere Smith, Letters to a Young Artist: Straight-up Advice on Making a Life in the Arts-For Actors, Performers, Writers, and Artists of Every Kind

I love performing on stage — no matter what. I thought that this declaration had long ago been tested and proven by the uncomfortable shows that I've done over the years. There was the theatre with the leaky dressing room, the dinner show with absolutely no playing space except in between patrons' tables with a few hammy, scene-stealing transvestites who had better legs than me, and, of course, growing up in Louisiana, outdoor dance recitals were heavenly — though dehydrating — bliss. I love to perform. Whether it's the fact that every performance could be your last, or that having people laugh with you (or maybe at you) is the best feeling in the entire world, nothing could make me give up my love for being onstage.

There were a few touch-and-go moments in this process to be sure. I fluctuated from downright miserable to precariously content many times during the rehearsal process, but just give me a costume, turn on the lights, cue up the music, and I'm back in the game. Performing this role felt pretty fantastic. Whether it was just relief that I didn't drop a load of dishes or that I didn't fall through the slats of the fire escape, the performances felt like second nature. Looking back, I am glad that my thesis role wasn't a perfect experience because I gained a very different 
experience on the stage than I ever expected, and I hope it will help me toward becoming a more seasoned actor.

My list of faults gets longer as the years go by, as everyone's does, but I can honestly say that certain moments in the rehearsal process brought out one of the major aspects of my personality that time just does not seem to want to dilute - my extreme sensitivity toward what other people think of me and how I often feel betrayed. (Hey, it worked for Bette Davis!) I can feel slighted at the drop of a hat, and while this is an issue that I will have to deal with for the rest of my life, any sort of solution others might offer just frustrates me. It's the reason that I didn't want to talk too much about my issues with anyone who had authority. I asked for help with a safety issue, but anything personal might just have made me seem like some whiny actor. Teachers and directors that I had in the past would always require me to enter into a state of vulnerability, where your heart is completely on your sleeve, and you're thereby able to fully live through what is going on onstage. I've never had trouble with this, and yet delivering what they want often brought the criticism offstage, “Oh, you've just got to toughen up; get a thicker skin!" The very thing that they asked of me was being shoved in my face, and I honestly didn't want that to happen this time. I didn't want there to be this kind of offstage drama stirred up for Kathleen, our director who was also a visiting artist, and also with graduate school being such a fish bowl, I just really felt like I needed to keep my head down and get through it. Truthfully, from my point of view, I was being hounded into a very negative situation with this other actor. I was being blamed in rehearsals for dropping lines when in fact it was his fault. Petty differences kept escalating, but I tried to keep a lid on my emotions. It was very difficult to see his point of view, but in actuality, he was probably going through an uphill battle as well. He replaced the initial Tom that was cast in the fall semester, and joined the family (so to speak) in January, 
which gave him little time to prepare. I can understand the troubles that plagued him, but in no way did I deserve to take the brunt of his frustrations. It wouldn't have mattered if I was as unyielding as John Wayne. I was being treated unfairly, and I responded by gritting my teeth during rehearsals, or shutting down, followed by explosions in my free time. It was the only way I felt that I could function. In retrospect, as much as I probably should have reached out more, I hate confrontation like the plague. I really didn't want to completely ruin the tenuous working relationship that we were struggling to build.

It was a very delicate balance to strike, but come performance time, things really did go swimmingly. Performing brought with it a sense of freedom that I couldn't find in rehearsals. Tenuously at first, a makeshift sense of trust was built on the stage. This was driven by a need of personal preservation - and it worked. I know that under different circumstances my performance could have been a lot stronger. I'm not trying to lay the blame on anybody's doorstep other than my own. The only actions I will ever be able to control are my own. And that's why I had to replace the Meisner Technique with Adler Technique, which promoted more individual responsibility in acting. You as the actor are in the driver's seat, and you're not a slave to what someone may or may not give you. Stella Adler's tenet of imagination in character development has always been a saving grace for me as far as acting techniques go. I'm very glad I had those tools to put to use. I could have spent more time researching before the start of rehearsals instead of stressing out about memorization. I could have asked for more one-on-one time with Kathleen (even if she thought everything was on track and didn't request a meeting after the first week). I could have stopped worrying so much about what little chemistry I felt I had on stage with others. But I didn't. I went through the process moment-to-moment with the best information I had at the time. Buckling down when things weren't such a picnic anymore 
and saying to myself, "Let's just get through it," was how I survived, and I was really pleased and pleasantly surprised at how I was able to return to a place of enjoyment once we were in performance. So, I'm a sensitive person, but I found a sense of resolve that came out of utter necessity. And, just to put a Pollyanna spin on this aspect of my personality - if I may be so bold - I think that being a very raw person has helped me as an actor. Being sensitive is just a fact; it's not an insult for me anymore.

There are many positives that I take from this experience as well (just in case I'm being too much of a Negative Nancy) because, in the long run, this role was an absolute gift as far as my acting education was concerned. I realized that I have the stamina to drive the plot, even though, as a character actor, I never really wanted that kind of responsibility. The play honestly flies by when it's being performed, and I felt like I had the necessary energy. I would love to take another shot at this role in about twenty years, when a professional performance might be possible. I'm glad that in educational theatre I've always gotten the older roles - the mother, maiden aunt, and even grandmother sometimes_-but I just want another crack at Amanda someday. Preferably, when I'm over fifty.

As far as gathering feedback, it would have been lovely if there had been someone to actually review the production instead of a staff writer for the school paper just reproducing the press release (that I penned for the department) after the show opened. I love reviews, though of course I haven't gotten a lot of them in my life. I have a desire to be graded or judged, if you will, and not having solid points of criticism from a review was a disappointment. It would have given me even more fodder for my personal conclusion of this process. But, of course, my main focus is always whether or not my parents will like a show that I'm in, and I'm glad that they did. They 
could hardly believe that there was ever a hiccup when they saw the penultimate performance, which was great. Score one for hiding hiccups.

This process (and the many ups and downs) does not cast a shadow on my time here at WVU. If anything, the year and a half that I had before coming into the process was just the preparation that I needed. My ultimate goal for my time here was not only to get a Master's degree so that I would be able to teach one day (which is a huge goal of mine) but to progress as a person and an actor. Multi-tasking and feeling like there are just not enough hours in the day, rigorous rehearsal schedules, and long-running performances have made me realize that I can endure a lot more than I thought I could. I can have issues and difficulties with others or situations, but this acting bug will never leave me. My experience here has made me confident in the fact that acting has not just been a flight of fancy, or incredibly expensive interest. It's a way of life. Come hell or high water, I've devoted myself to this profession, with a few battle scars to prove it. I can call myself an actor, or dare I say, an artist, without a twinge of apology or regret. So, in conclusion: for me, there's definitely no business like show business! 


\section{Works Cited}

\section{$\underline{\operatorname{Script}(s):}$}

Williams, Tennessee. The Glass Menagerie. New York: New Directions, 1999. Print.

Williams, Tennessee. The Glass Menagerie. New York: Dramatists Play Service, 1998. Print.

$\underline{\text { Books/Electronic Dissertations: }}$

Adler, Stella, and Howard Kissel. The Art of Acting. New York: Applause, 2000. Print.

Adler, Stella. "The Glass Menagerie (1945)." Stella Adler on America's Master Playwrights:

Eugene O'Neill, Thornton Wilder, Clifford Odets, William Saroyan, Tennessee Williams, William Inge, Arthur Miller, Edward Albee. New York: Alfred A. Knopf, 2012. 224-44. Print.

Hagen, Uta, and Haskel Frankel. Respect for Acting. Hoboken, NJ: John Wiley \& Sons, 2008. eBook.

Janardanan, Dipa. "Images of Loss in Tennessee Williams' ‘The Glass Menagerie,' Arthur Miller's ‘Death of a Salesman,' Marsha Norman's 'Night, Mother,' and Paula Vogel's 'How I Learned to Drive'." Diss. Georgia State University, 2007. Ann Arbor: ProQuest Dissertations and Theses. Web. 5 August 2014.

Smith, Anna Deavere. Letters to a Young Artist: Straight-up Advice on Making a Life in the Arts—For Actors, Performers, Writers, and Artists of Every Kind. New York: Anchor, 2006. Print.

Thornton, Margaret Bradham. Introduction. Notebooks. By Tennessee Williams. 1936-1981. New Haven: Yale UP, 2006. N. pag. Print.

Williams, Edwina Dakin and Lucy Freeman. Remember Me to Tom. St. Louis: Sunrise, 1980. Print. 
$\underline{\text { Website Articles: }}$

Collins, William B. "The Playwright's Mother Haunts 'Glass Menagerie'" Philly.com. The Inquirer, 11 Dec. 1989. Web. 31 May 2014.

"Columbus: Tennessee Williams \& Eudora Welty." Southern Literary Trail. Web. 13 Oct. 2014.

Gottlieb, Robert. "The Greatest 'Menagerie'" The New Yorker. N.p., 18 Oct. 2013. Web. 31 May 2014.

Hernandez, Greg. “ 'Designing Women’ Thursday: Here Is Why Dixie Carter's Julia Sugarbaker Was Called the Terminator." Greg in Hollywood Atom. N.p., 15 Apr. 2010. Web. 14 May 2014.

Jacob, Susannah. "Blow Out Your Candles: An Elegy for Rose Williams." The Paris Review RSS. The Paris Review, 5 Dec. 2013. Web. 27 Sept. 2014.

\section{Media Sources:}

The Glass Menagerie. Dir. Paul Newman. Perf. John Malkovich and Joanne Woodward.

Cineplex Odeon Films, 1987. Videocassette.

"Playing the Swan.” Slings and Arrows: The Complete Collection. Writ. Susan Coyne, Bob Martin, Mark McKinney, and Tecca Crosby. Dir. Peter Wellington. Acorn Media, 2003. DVD.

Summer and Smoke. Dir. Peter Glenville. Perf. Geraldine Page and Laurence Harvey. Paramount Pictures, 1961. Netflix.

Toys in the Attic. Dir. George R. Hill. Perf. Geraldine Page and Dean Martin. United Artists, 1963. DVD. 